\title{
Consolidating the State of Knowledge: A Synoptical Review of Wind Energy's Wildlife Effects
}

\author{
Eva Schuster $^{1} \cdot$ Lea Bulling $^{1} \cdot$ Johann Köppel $^{1}$
}

Received: 10 August 2014/ Accepted: 10 April 2015/Published online: 26 April 2015

(C) Springer Science+Business Media New York 2015

\begin{abstract}
Wind energy development contributes substantially to achieve climate protection goals. Unintended side effects, especially on wildlife, have long been discussed and substantial research has evolved over the last decade. At this stage, it is important to identify what we have learnt so far, as well as which predominant uncertainties and gaps remain. This review article aims to consolidate the state of knowledge, providing a qualitative analysis of the main effects of wind energy development on- and offshore, focusing on frequently studied species groups (bats, breeding and resting birds, raptors, migratory birds, marine mammals). We reviewed over 220 publications from which we identified predominant hypotheses that were summarized and displayed in tables. Journal publications, conference contributions, and further studies have been considered. We found that research focusing on offshore wind energy within the last couple of years has increased significantly as well, catching up with the vast amount of onshore studies. Some hypotheses have been verified by numerous publications and a consensus has been reached (e.g., correlation between bat activity and weather factors), while others are still being debated more (e.g., determination of migratory corridors) or remain unknown (e.g., effect on population level). Factors influencing potential effects were mainly related to species characteristics (morphology, phenology, abundance, behavior, and response to turbines) or site characteristics (landscape features, weather, and habitat quality).
\end{abstract}

Eva Schuster

eva.schuster@tu-berlin.de

1 Environmental Assessment and Planning Research Group, Berlin Institute of Technology, Strasse des 17. Juni 145, 10623 Berlin, Germany
Consolidating the state of research provides the groundwork for the identification of mitigation measures and advanced planning approaches. However, the quantification of effects remains challenging and uncertainties will always persist.

Keywords Wind energy and wildlife effects · Influencing factors - Bats - Raptors - Breeding and resting birds .

Migratory birds $\cdot$ Marine mammals

\section{Introduction}

The increase of the global mean surface temperature is likely to exceed $1.5-2.0{ }^{\circ} \mathrm{C}$ by the end of the twenty-first century. However, these estimations include the assumption that we will have achieved climate protection goals on a global scale, in particular the significant reduction of $\mathrm{CO}_{2}$-emissions (IPCC 2013). The development of renewable energies is a promising tool in order to tackle this challenge. At the same time, wind energy development can generate effects on wildlife, raising concern about affected species (e.g., Bailey et al. 2010; Kunz et al. 2007; Smallwood and Thelander 2008). Numerous surveys have been carried out within this field of research, with a focus on bats, birds, marine mammals, fish, and benthos, to understand the mechanisms behind these effects and to use this knowledge for the development of mitigation measures and planning tools. Hence, it is essential to showcase what we have learnt so far and which uncertainties remain to allow for a sensitive wind energy development and to focus future research on shortcomings so far.

A number of partial syntheses have already been published (e.g., Arnett et al. 2011a; Arnett and Baerwald 2013; Bergström et al. 2013b; Helldin et al. 2012; Lovich and 
Ennen 2013; Rydell et al. 2012). They have focused on specific species groups, locations, or countries, whereas a comprehensive survey is still lacking. With this review article, we aim for a consolidation of current knowledge by providing a qualitative overview of major effects regarding bats, birds, marine mammals, and the factors that are likely to influence these effects. Hypotheses which have been discussed within peer-reviewed publications, further studies, and conference contributions have been highlighted. The species group "birds" has been sub-classified due to its heterogeneity, resulting from different behavior and habitat use. Subsequently, effects on bats, breeding and resting birds, raptors, migratory birds offshore, and marine mammals are outlined.

Implications on other species groups must be recognized as well, such as terrestrial mammals, seabirds, fish and benthos. Beyond wildlife impacts, it is also essential to assess possible effects wind farm development may have on scenery and human health (e.g., Knopper and Ollson 2011). However, these effects have not been covered in this article.

\section{Methods}

This review presents a qualitative analysis of international research in the field of wind energy and wildlife interactions on- and offshore. We reviewed over 220 documents covering different publication types, i.e., peer-reviewed articles, peer-reviewed synthesis, reports (gray literature), and conference material, all of which had been openly accessible or published in scientific journals up until 2014. We have reviewed contributions of recent international conferences such as the Conference on Wind Energy and Wildlife impacts (CWW 2011, Trondheim, Norway), the Conference on Wind Power and Environmental Impacts (CWE 2013, Stockholm, Sweden), the biennial Wind Wildlife Research Meetings (by the NWCC, U.S.), the WINMON.BE Conference (2013 in Brussels, Belgium), and the StuKplus Conference 2013 (Berlin, Germany), along with available publications that evolved from them. We used further references to cover additional studies. Thus, we identified predominant hypotheses on potential effects including factors of positive or negative influence (e.g., site characteristics, weather patterns, and species behavior). The findings have been summarized and presented in tables, displaying research results and deductions, which state the main hypotheses as plausible or implausible. We indicate with symbols in the tables whether findings originate from peer-reviewed contributions or gray literature as well as from original research or literature reviews. Through this process, we were able to cover the state of research, at the same time being aware of the heterogeneous methodologies and frameworks that often impede direct comparisons of results. Moreover, review articles provide an important contribution by analyzing a variety of publications and drawing more comprehensive conclusions. In some cases, however, they cover the findings of some original research that was also included in the analysis. This needs to be taken into account when reading the tables. Furthermore, the listed hypotheses are not mutually exclusive and are open for further amendments. For case-specific impact assessments, species- and site-specific variations need to be considered.

\section{Main Impacts on Bats}

Today we know that fatality rates of bats can outnumber those of birds at most wind energy facilities. However, observed and estimated fatality rates vary widely between studies (e.g., Rydell et al. 2012). During operation, habitat loss or deterrence due to ultrasonic sounds (Brinkmann et al. 2011) might occur. Nevertheless, effects resulting from direct or indirect contact with moving turbine blades are the subject of main concern (e.g., Brinkmann et al. 2011), causing lethal or sub-lethal injuries (Grodsky et al. 2011). The reasons why bats are colliding have not yet been fully understood. Referring to Cryan and Barclay (2009), there are proximate causes of bat fatality, implying direct collision and barotrauma. Additionally, collision can be explained by ultimate causes, comprising why bats approach moving turbine blades, including either random collision (presence of bats), coincidental collision (e.g., flight behavior), or collision as a result of attraction (Cryan and Barclay 2009).

\section{Spatial Patterns of Collision During Operation}

It was observed that bats were killed by direct collision with moving turbine blades, but not by stationary blades, nacelles, or towers (Arnett 2005; Horn et al. 2008). Bats with visual injuries found dead or injured underneath turbines have been associated with physical contact with moving turbine blades (Baerwald et al. 2008). Furthermore, Horn et al. (2008) reported bats being hit by moving blades but continued flying in an altered direction. An unknown number of offsite deaths due to such sub-lethal injuries can lead to even higher fatality rates (Grodsky et al. 2011).

Bat collision seems to be randomly distributed among turbines and therefore unlikely to be turbine-specific (Arnett et al. 2008; Fiedler et al. 2007). It was observed that turbines with high fatalities were often located at the end of turbine strings (Arnett et al. 2008; Kerns et al. 2005) or close to the shoulder of ravines, which could only be observed in one of the two survey years (Piorkowski and 
O'Connell 2010). Baerwald and Barclay (2011) did not observe turbine-specific patterns when comparing facilities from the easterly to the westerly side of the wind farm, nor between turbines at the end of a row compared to the middle of a row. However, they found higher fatality rates at turbines in the north compared to the south of the wind farm, as those would be the first turbines to be encountered by migratory bats when flying from north to south (Baerwald and Barclay 2011).

\section{The Theory of Barotrauma}

Nevertheless, not all carcasses showed external injuries. Necropsy and histopathology results revealed internal injuries, indicating barotrauma (Baerwald et al. 2008). Baerwald et al. (2008) stated that barotrauma, which is caused by a sudden decrease in air pressure resulting in severe hemorrhaging, might cause up to $90 \%$ of fatalities. Others who did not support this hypothesis like Piorkowski and O'Connell (2010) found that $82 \%$ of dead bats $(n=17)$ had broken bones whereas $18 \%$ had no skeletal injuries. Grodsky et al. (2011) stated that bone fractures, as a result of direct collision, might often remain undiscovered by visual inspection alone. Grodsky et al. (2011) and Rollins et al. (2012) further imply that other factors such as postmortem time, environmental temperature, and freezing of carcasses could mimic the diagnostic criteria for pulmonary barotrauma. It remains debated whether a combination of direct collision and barotrauma (Grodsky et al. 2011) or direct collision alone might be responsible for most fatalities. More recent studies questioned the existence of barotrauma at all (Houck 2012; Rollins et al. 2012).

Additionally, it was observed that bats were trapped in vortices behind the moving blades (Horn et al. 2008) which might also be interpreted as bats chasing after the slowmoving blades (Arnett 2005). However, it is possible that bats are being contorted by the air currents from moving turbine blades, which may result in injury, e.g., dislocation or breaking of wing bones (Grodsky et al. 2011).

\section{Avoidance and Awareness}

The aforementioned facts still do not explain why bats are being killed by moving turbine blades. It had been hypothesized that bats do not or only in part use echolocation during migration (Bach 2001 in Behr et al. 2007) and therefore would be unable to locate the moving blades. However, various authors have recorded echolocation activity during migration (e.g., Ahlén et al. 2009; Furmankiewicz and Kucharska 2009), which would question this hypothesis. Additionally, bats have shown active avoidance behavior (Brinkmann et al. 2006; Horn et al.
2008) and have been observed attempting to land on turbines to gather insects or to roost, offshore (Ahlén et al. 2009) as well as onshore (Arnett 2005; Horn et al. 2008). A recent study by Cryan et al. (2014) stated that during late summer and autumn, bats were actively approaching wind turbines, particularly in conditions with low winds, when turbines were non-operational or when blades were slowmoving, using vision, echolocation, and minimal turbulent air currents for orientation.

This indicates that bats are aware of the physical presence of turbines. They also do not collide when turbines are non-operational (Arnett 2005; Horn et al. 2008). Collisions with other anthropogenic structures, such as buildings or television towers, had been reported but appear to be very low (Arnett 2005) indicating that bat collision is strongly linked to blade movement (Rydell et al. 2010a). It was stated that even by using echolocation, the rapidly moving turbine blades, especially the tips $(100-150 \mathrm{~m} / \mathrm{s})$, are still hard to detect in time and thus to avoid (Grodsky et al. 2011; Long et al. 2009; Rydell et al. 2010a).

\section{Weather Patterns Influencing Bat Activity}

Bat activity and fatality is strongly influenced by weather variables (e.g., Baerwald and Barclay 2011). These parameters can be used to predict times of high collision risk, serving as groundwork for the development of effective mitigation approaches (Brinkmann et al. 2011). Weather parameters such as wind speed, temperature, and precipitation (Behr et al. 2011), as well as barometric pressure (Kerns et al. 2005) and moon illumination (Baerwald and Barclay 2011; Cryan et al. 2014) correlated with bat activity or fatalities in numerous studies. Nevertheless, the influence of each weather variable on bat activity varies between species (Baerwald and Barclay 2011; Behr et al. 2011).

Wind speed is a major parameter to predict times of high bat collision risk (e.g., Baerwald and Barclay 2011; Behr et al. 2011). Redell et al. (2006) and Arnett et al. (2006) reported that bat activity decreased by 4-13 and 11-39\% with every $1 \mathrm{~m} / \mathrm{s}$ increase in wind speed. Another study from Rydell et al. (2010a) synthesized that activity was highest at wind speeds of $0-2 \mathrm{~m} / \mathrm{s}$. With further increase in wind speed $(2-8 \mathrm{~m} / \mathrm{s})$, activity declined until it almost stopped completely. This was also reported by Behr et al. (2007) at wind speeds higher than $6.5 \mathrm{~m} / \mathrm{s}$. These findings imply that the majority of bats are killed during nights with slow-moving blades and circumstantial generated electricity (Arnett 2005, et al. 2011c; Baerwald et al. 2009). Arnett et al. (2008) estimated for two wind farms in the U. S. that bat fatality would have been reduced by 82 and $85 \%$, respectively, if turbines had not been operating during nights with mean wind speeds of $<6 \mathrm{~m} / \mathrm{s}$ during late summer (1 Aug-13 Sep). 
Additionally, research from numerous studies found that bat activity increased with increasing temperature. Arnett et al. (2006) stated an increase in activity by $7-13 \%$ at $1.5 \mathrm{~m}$ and $0-7 \%$ at $22 \mathrm{~m}$ altitude for every degree Celsius up to $19-21{ }^{\circ} \mathrm{C}$. Redell et al. (2006) reported a different increase in activity of bat species echolocating within a low-frequency range (7-13\%) than species using highfrequency echolocation (3-9 \%) per degree Celsius. Arnett et al. (2007) also reported activity differences of the two phonic groups in relation to air temperature. However, the high-frequency group showed a stronger response to temperature than the low-frequency group. Furthermore, in nights with high temperature $\left(\geq 20^{\circ} \mathrm{C}\right)$ and moderate wind speed $(8 \mathrm{~m} / \mathrm{s})$, bat activity was low among bats using lowfrequency echolocation (Arnett et al. 2007). Arnett et al. (2006) observed further that temperatures above $21^{\circ} \mathrm{C}$ and higher led to a decrease in bat activity, whereas activity was not affected by temperatures above an altitude of $44 \mathrm{~m}$ at all. However, Horn et al. (2008) and Kerns et al. (2005) did not confirm temperature as an independent factor to significantly predict bat activity at the Mountaineer Wind Energy Center, West Virginia.

A German study from Behr et al. (2011) stated that in addition to the external factors wind speed and air temperature, humidity in particular (fog, clouds with 0002$0004 \mathrm{~mm} / \mathrm{min}$ ) strongly decreased bat activity. A multivariate regression analyzes including wind speed, temperature, and turbine rotation speed could be used to predict bat passes (Horn et al. 2008). Furthermore, Kerns et al. (2005) stated an instant increase in bat activity before and after the passage of storm fronts associated with high air pressure, whereas Baerwald and Barclay (2011) and Cryan and Brown (2007) observed increasing bat activity with decreasing barometric pressure. Moon illumination might also increase bat activity (Baerwald and Barclay 2011; Cryan et al. 2014), which was not confirmed by Cryan and Brown (2007), where low moon illumination together with low wind speeds and high cloud cover predicted bat arrival and departures.

\section{Seasonal Patterns of Bat Activity}

Bat activity and fatality also show a seasonal pattern. Preand post-construction studies from all over the world revealed that during late summer and autumn, bat activity and mortality appeared to be highest (e.g., Arnett et al. 2006; Dürr 2002; Southern hemisphere: Doty and Martin 2012; Hull and Cawthen 2013). Endl et al. (2004 in Rydell et al. 2010a) noted that $90 \%$ of the annual mortality occurred in August-September, whereas only $10 \%$ appeared in early June.

This might indicate that bat fatality is linked to migration behavior, with a strong emphasis on autumn migration.
Johnson et al. (2011) stated that migration patterns underlie a strong species-seasonal-regional-specificity. However, this does not exclude that migration patterns might exist on landscape or regional levels (Kerns et al. 2005). Generally, autumn migration takes place over a longer time period with a number of stop-overs, most likely due to foraging and mating behavior, which differs between nectarivorous and insectivorous species. During spring migration, bats tend to fly straight to their summer roosts in order to occupy foraging territories and recover (Furmankiewicz and Kucharska 2009), likely to result in a decrease in risk of collision. A study from Europe, however, showed that during spring migration, bats tend to disperse when migrating over sea (Ahlén et al. 2009). Furmankiewicz and Kucharska (2009) also stated that autumn migration appears to happen at lower elevation than spring migration. Variation in weather conditions and foraging behavior linked to the accumulation of pre-hibernation fat and energy demand can also lead to differences in spring and autumn migration (Furmankiewicz and Kucharska 2009). Behr et al. (2007) observed that bat activity was high not only during autumn migration but also during times when bats left their summer-colonies (July-August). Seasonal behavior in general, not only migration, might be linked to the mechanisms behind bat fatalities. Migration periods might simply lead to an increase of bat occurrence and therefore a higher number of individuals being at collision risk during stop-overs to feed, drink, roost, or mate (Cryan and Brown 2007).

\section{Offshore Bat Migration}

Ahlén et al. (2009) observed migration behavior of bats offshore and reported that 11 out of 18 species appeared up to $14 \mathrm{~km}$ off coast. At least ten species, not only migrants but also residents, had been foraging there. Bat observations have also been reported from the Southeast Farallon Island, $32 \mathrm{~km}$ off the coast of California for many years, with hoary bats using the island as a migration stopover point (Cryan and Brown 2007). According to Ahlén et al. (2009), flight altitude during migration appears to be very low above sea level $(<10 \mathrm{~m})$, which is likely to be linked to altered orientation techniques, also in terms of an alteration of echolocation signals. However, as soon as bats flew close to vertical structures such as wind turbines, they rapidly increased flight elevation which is likely linked to an accumulation of insects. Contradictory to these findings, Hatch et al. (2013) who observed bats flying 16.9-41.9 km off the coast reported that migratory bats flew at relatively high altitudes at $>100 \mathrm{~m}$ ( 6 bats out of 6$)$ and $>200 \mathrm{~m} \mathrm{(5}$ bats out of 6) above sea level. Migration behavior took place during daylight also, which might be due to a lack of landing opportunities. Bat activity peaked in September 
and during relatively strong tailwinds $(8.9-10.1 \mathrm{~m} / \mathrm{s})$ (Hatch et al. 2013).

Ahlén et al. (2009) concluded that the risk of collision during migration offshore is likely to be low. In contrast, the risk appears to be high for migrating and resident species during foraging, especially in areas with high bat occurrence (e.g., close to departure points near the coast) and also under weather conditions that attract insects. However, Cryan and Brown (2007) stated that hoary bats congregate around the tallest structure along their migration corridor in autumn, which might put them particularly at risk of collision with offshore wind facilities. Sjollema et al. (2014) argue that offshore wind farms might even result in similar fatality rates as estimated for onshore facilities. Within their study, at a maximum distance of $21.9 \mathrm{~km}$ off the shore (mean distance $8.4 \mathrm{~km}$ ), bat activity could be recorded. Further, activity did not differ with distance to the coast (Sjollema et al. 2014).

\section{Morphological and Ecological Similarities of Species at Risk}

Many authors have stated that long-distance migratory bats are those most frequently killed, particularly in North America (Arnett et al. 2008; Horn et al. 2008; Cryan and Barclay 2009; Kunz et al. 2007). Other studies from Europe (e.g., Behr et al. 2007; Brinkmann et al. 2006; Rydell et al. 2010a, b; Voigt et al. 2012) and Australia (Hull and Cawthen 2013) did not confirm that migratory bats are at higher risk then resident species. Voigt et al. (2012), using stable hydrogen isotope analysis, found that among bats killed in Germany were not only individuals of more local populations (P. pipistrellus) but also migratory ones from Estonia or Russia (P. nathusii) and Scandinavia (N. nocutal, N. leisleri).

However, Hull and Cawthen (2013) and Rydell et al. (2010b) synthesized that bat species particularly vulnerable to collision, though of different genera, do have some morphological and ecological similarities. Species at high collision risk within North America (Lasiurus, Lasionycteris, Perimyotis), Europe (Nyctalus, Pipistrellus, Vespertilio, Eptesicus), and Australia (Chalinolobus gouldii) are open-air foragers with long and narrow wings, using high-intensity narrow-band echolocation calls to detect moving insects during flight. Rydell et al. (2010a) stated that $98 \%$ of the killed bats account as open-air foraging, while ca. $60 \%$ of species are most likely at low or no risk due to flight altitudes below the rotor swept zone and the tendency to avoid open space.

\section{Age and Sex of Frequently Killed Bats}

The hypothesis that mortality among juveniles and subadults would be higher due to low flight ability was only confirmed by Fiedler et al. (2007). This was not confirmed by other studies that combined juveniles and subadults as one group. Hull and Cawthen (2013) found that the majority of fatalities were male and female adults at equal ratios. Studies across North America showed that there was a predominant tendency toward adult males being killed (Arnett et al. 2008). Further, Rydell et al. (2010a) suggest that age and sex of bat fatalities vary among locations, except for facilities that are in close range of maternity colonies. A study from Oklahoma reported 111 dead bats of which $85 \%$ had been Brazilian free-tailed bats (Tadarida brasiliensis), mostly pregnant. The facility under observation was located $15 \mathrm{~km}$ away from a maternity colony, implying that during the study period (May-June 2004 and May-July 2005), the female bats left the colony for feeding (Piorkowski and O'Connell 2010).

\section{Food Availability}

Horn et al. (2008) observed a significant correlation between insect and bat activity during all nights, with an activity peak during the first $2 \mathrm{~h}$ after sunset. Thermal infrared images showed bats actively feeding around the turbine blades, and also investigating the nacelles and blades due to repeated fly-bys (Horn et al. 2008). Other onshore studies stated that bats had been killed during or after feeding (Rydell et al. 2010a; Grodsky et al. 2011). Grodsky et al. (2011) reported $25 \%$ of the casualties had a full stomach. Ahlén et al. (2009) also observed high bat activity offshore in areas where prey abundance was high. Additionally, insect abundance is likely to be driven by similar weather patterns such as low wind speed and temperatures higher than $10{ }^{\circ} \mathrm{C}$ (Corten and Veldkamp 2001). This may result in either a direct (higher abundance of prey correlating with high bat activity) and/or indirect (higher abundance of bats and insects during similar weather conditions) bat activity and insect abundance relation. Cryan et al. (2014) who could not observe frequent foraging behavior stated that at wind speeds of $>1 \mathrm{~m} / \mathrm{s}$, bats approached the moving blades leeward. Since it is known that bats often fly behind windbreaks, e.g., forest edges, the authors hypothesized that bats might expect the same habitat benefits downwind turbine blades, such as increased insect abundance (Cryan et al. 2014). Moreover, it was found by Horn et al. (2008) that insect abundance appeared to be slightly higher around Federal Aviation Administration (FAA) lights, but a difference in bat abundance at lit turbines compared to unlit turbines could not be observed, and was also confirmed by others (Baerwald and Barclay 2011; Johnson et al. 2003; Kerns et al. 2005). 


\section{Roosting and Mating Behavior}

Hull and Cawthen (2013) stated that five out of six killed bats had not been feeding, whereas only the sixth bat had insects in its intestinal tract. They hypothesized that mating and roosting behavior and not food availability is what draws bats to wind turbines. It is conceivable that the turbine silhouettes within open landscapes are mistaken as possible roost-trees (Cryan et al. 2014; Kunz et al. 2007) and therefore scrutinized by tree-roosting bats, which might result in a higher risk of collision. A recent study by Cryan et al. (2014) suggests that bats approach turbines in the same manner as tall trees, by using not only visual cues for orientation but also by sensing air currents. The authors hypothesized that airflow around stationary or slowly operating turbines might be similar to the air currents around tall trees. This was supported by the fact that bats were more active around stationary or slow-moving turbines, but approached the turbines less frequently in times of fast rotating blades. In these conditions, when airflows change into "chaotic downwind turbulence," the turbine surrounding might occur as unfavorable in terms of prey availability and energy consumption. This hypothesis might explain the high fatality rate of tree-roosting but not necessarily of cave roosting bats. However, it cannot be excluded that these species might also approach trees on some occasions (Cryan et al. 2014). In this context, it has been debated (ibid.) whether lower fatality numbers of eastern red bats (Lasiurus borealis) at turbines with flashing red FAA lighting could be explained by an enhanced differentiation of wind energy facilities from trees (Bennett and Hale 2014).

\section{Landscape Features Influencing Bat Activity}

Studies on bat migration implied that bats use linear landmarks like river valleys (e.g., Furmankiewicz and Kucharska 2009), coast lines of the Baltic, North and Black Sea, tree rows, stone dikes, and forest edges (e.g., Ahlén et al. 2009) as corridors where they migrate concentratedly (Baerwald and Barclay 2009). Arnett et al. (2006: at $44 \mathrm{~m}$ ) and Piorkowski and O'Connell (2010) did not observe any significant relations between different habitat types or ground cover, while the study of Johnson et al. (2004) stated a significant decrease in bat activity with rising distance to woodlands. Brinkmann et al. (2006) observed no differences in bat activity between forested areas and open landscapes at $>40 \mathrm{~m}$ altitude. However, the fatality searches revealed a high rate within forested areas and no fatalities in the open landscape. Baerwald and Barclay (2009) observed higher activity rates for hoary bats ( $L$. cinereus) and silver-haired bats (L. noctivagans) near foothills of the Rocky Mountains than on prairie grassland, likely linked to the availability of stopover and roosting sites, as well as geographical landmarks. Rydell et al. (2010a) reviewed reports from northwestern Europe, comparing bat mortality related to a landscape gradient. They concluded that relatively low numbers $(0-3$ bats per turbine) were killed annually on flat terrain in the midlands (e.g., open farmland). However, within more heterogeneous agricultural land, the rate increased ( $2-5$ bats per turbine). The highest rates (5-20 bats per turbine) were reported from coastal or forested areas, especially on hills and ridges (Rydell et al. 2010a). Ahlén (2003) stated that coastlines and areas located close to large lakes might account as high-risk areas due to high insect abundance. (cf. Table 1).

\section{Main Impacts on Wildlife Onshore}

\section{Breeding and Resting Birds}

Drewitt and Langston (2006) identified collision, displacement, barrier effects, habitat change, and habitat loss as the main effects wind farms can have on birds. As many avian resting areas overlap with regions of high wind yield, the potential impacts cannot be neglected (Isselbächer and Isselbächer 2001). The major hypotheses on wind energyinduced effects on breeding, wintering and passaging birds in the open landscape are summarized in Table 2. This section comprises the following effects on these birds: Breeding and wintering, passaging through, covering songbirds, waders, and geese. These habitats have an open character, either due to agricultural use or naturally, such as peatlands. Often the same species are classified differently, e.g., as upland birds (Douglas et al. 2011; Pearce-Higgins et al. 2012), peatland birds (Pearce-Higgins et al. 2008), or wintering farmland birds (Devereux et al. 2008), and are considered as breeding and resting birds here. Due to diverging behavioral patterns, effects on raptors are addressed separately in "Raptors" section.

\section{Construction Effects}

Several authors have analyzed the impacts of wind farm construction on birds and found both positive and negative effects. Pearce-Higgins et al. (2012) observed a non-significant increase of curlews (Numenius arquata) on a nearby wind farm reference site during construction. The additional curlews were presumably displaced by construction activity within the wind farm area and relocated to breed within the reference site. Adversely, the densities of stonechat (Saxicola rubicola), skylark (Alauda arvensis), and meadow pipit (Anthus pratensis), for example, increased during the time of construction. This was explained 
Table 1 Predominant hypotheses on wind energy-induced effects on bats based on Köppel et al. (2014 amended)

\begin{tabular}{|c|c|c|}
\hline Hypothesis & Plausible/supported & Implausible/not-supported \\
\hline \multicolumn{3}{|l|}{ Increased mortality due to high flight activity } \\
\hline $\begin{array}{l}\text { Increase in temperature enhances bat } \\
\text { activity/fatality (up to } 21^{\circ} \mathrm{C} \text { ) }\end{array}$ & $\begin{array}{l}\text { Arnett et al. }\left(2006^{\delta}, 2007\right)^{\delta} \text {, Baerwald and } \\
\text { Barclay }(2011)^{*} ; \text { Behr et al. }(2011)^{\delta}, \\
\text { Brinkmann et al. }(2011)^{\delta} \text {, Grodsky et al. } \\
(2012)^{*} \text {, Hein et al. }(2011 b)^{\delta}, \text { Kerns et al. } \\
(2005)^{\delta} \text { : Meyersdale, and Redell et al. } \\
(2006)^{\delta}\end{array}$ & $\begin{array}{l}\text { Arnett et al. }(2006)^{\delta}(>44 \mathrm{~m}) \text {; Horn et al. } \\
(2008)^{*} \text { : but in combination with wind speed; } \\
\text { Kerns et al. }(2005)^{\delta}: \text { Mountaineer }\end{array}$ \\
\hline $\begin{array}{l}\text { Decrease in wind speed leads to a higher } \\
\text { bat activity/fatality }\end{array}$ & $\begin{array}{l}\text { Arnett et al. }\left(2006^{\delta}, 2008^{\mathrm{f}}\right) \text {, Baerwald et al. } \\
(2009)^{*}, \text { Baerwald and Barclay }(2011)^{*}, \text { Behr } \\
\text { et al. }\left(2007^{*}, 2011^{\delta}\right), \text { Brinkmann et al. } \\
(2011)^{\delta}, \text { Hein et al. }(2011 \mathrm{~b})^{\delta} \text {, Horn et al. } \\
(2008)^{*}, \text { Kerns et al. }(2005)^{\delta} \text {, and Redell } \\
\text { et al. }(2006)^{\delta}\end{array}$ & $\begin{array}{l}\text { Arnett et al. }(2007)^{\delta} \text { : highest at moderate wind } \\
(8 \mathrm{~m} / \mathrm{s}) \text { and high temperature; Grodsky et al. } \\
(2012)^{*} \text {, Hein et al. }(2011 \mathrm{~b})^{\delta} \text { : low-frequency } \\
\text { bats }\end{array}$ \\
\hline $\begin{array}{l}\text { High bat fatality/activity in times of high } \\
\text { air pressure }\end{array}$ & $\begin{array}{l}\text { Kerns et al. }(2005)^{\delta} \text { (before and after storm } \\
\text { fronts) }\end{array}$ & $\begin{array}{l}\text { Baerwald and Barclay (2011)* (hoary bat), } \\
\text { Cryan and Brown }(2007)^{*} \text {, and Horn et al. } \\
(2008)^{*}\end{array}$ \\
\hline $\begin{array}{l}\text { High bat activity/fatality in times with very } \\
\text { low humidity }\end{array}$ & $\begin{array}{l}\text { Behr et al. }(2011)^{\delta} \text {, Brinkmann et al. }(2011)^{\delta} \text {, } \\
\text { and Kerns et al. }(2005)^{\delta}\end{array}$ & \\
\hline $\begin{array}{l}\text { High bat activity/fatality during moonlit } \\
\text { nights }\end{array}$ & $\begin{array}{l}\text { Baerwald and Barclay (2011)*, and Cryan et al. } \\
\text { (2014)* }\end{array}$ & $\begin{array}{l}\text { Cryan and Brown }(2007) * \text { (low moon } \\
\text { illumination together with low wind speeds, } \\
\text { and relatively high degrees of cloud cover) }\end{array}$ \\
\hline $\begin{array}{l}\text { Increased bat activity/fatality during sunset } \\
\text { and few hours after sunset }\end{array}$ & $\begin{array}{l}\text { Arnett et al. }(2006)^{\delta} \text { : also sunrise; Behr et al. } \\
(2007)^{*}, \text { Brinkmann et al. }(2011)^{\delta}, \text { Hein et al. } \\
(2011 \mathrm{~b})^{\delta} \text { : high-frequency bats and hoary bat; } \\
\text { and Horn et al. }(2008)^{*}\end{array}$ & \\
\hline $\begin{array}{l}\text { Increased bat fatality during late summer/ } \\
\text { autumn }\end{array}$ & $\begin{array}{l}\text { Amorim et al. (2012)*, Arnett et al. }\left(2006^{\delta} \text {, }\right. \\
\text { 2008) })^{\mathrm{f}} \text {, Behr et al. (2007)* (July-Oct), } \\
\text { Brinkmann et al. }(2006)^{\delta} \text {, Brinkmann et al. } \\
(2011)^{\delta} \text { : July/August; Cryan and Brown } \\
(2007)^{*} \text {, Doty and Martin }(2012)^{*} \text { : southern } \\
\text { hemisphere; Grodsky et al. }(2012)^{*} \text {, Hein } \\
\text { et al. }(2011 \mathrm{~b})^{\delta} \text {, Jain }(2005)^{\delta} \text {, Johnson et al. } \\
\left(2003^{*}, 2004\right)^{*}, \text { Redell et al. }(2006)^{\delta} \text {, and } \\
\text { Rydell et al. }(2010 \mathrm{~b})^{\mathrm{f}}\end{array}$ & \\
\hline \multicolumn{3}{|l|}{ Increased mortality due to flight behavior } \\
\hline Migratory species particularly at risk & $\begin{array}{l}\text { Arnett et al. }(2008)^{\mathrm{f}} \text {, Baerwald et al. (2009)*, } \\
\text { Cryan and Brown }(2007)^{*} \text {, Cryan and Barclay } \\
(2009)^{\mathrm{f}} \text {, Grodsky et al. }(2012)^{*} \text {, Johnson et al. } \\
\left(2003^{*}, 2004^{*}\right) \text {, and Kunz et al. }(2007)^{\mathrm{f}}\end{array}$ & $\begin{array}{l}\text { Ahlén }(2003)^{\delta}, \text { Brinkmann et al. }(2006)^{\delta} \text {, Behr } \\
\text { et al. }(2007)^{*} \text {, Hull and Cawthen }(2013)^{*}, \\
\text { Rydell et al. }(2010 \mathrm{a})^{\mathrm{f}} \text {, and Voigt et al. }(2012)^{*}\end{array}$ \\
\hline $\begin{array}{l}\text { Use of echolocation during flight, reaction } \\
\text { time insufficient }\end{array}$ & $\begin{array}{l}\text { Grodsky et al. }(2011)^{*}, \text { Kunz et al. }(2007)^{\mathrm{h}} \text {, } \\
\text { Long et al. }(2009)^{\delta} \text {, and Rydell et al. }(2010 \mathrm{a})^{\mathrm{f}}\end{array}$ & \\
\hline $\begin{array}{l}\text { Increased risk for sub-adults (e.g., lower } \\
\text { flight ability) }\end{array}$ & Fiedler et al. $(2007)^{\delta}$ (sub-adults and juveniles) & $\begin{array}{l}\text { Arnett et al. }(2008)^{\mathrm{h}} \text {, Grodsky et al. }(2012)^{*} \text {, } \\
\text { Hull and Cawthen }(2013)^{*} \text {, Johnson et al. } \\
(2004)^{*}, \text { Kerns et al. }(2005)^{\delta} \text {, and Rydell } \\
\text { et al. }(2010 \mathrm{a})^{\mathrm{f}}\end{array}$ \\
\hline $\begin{array}{l}\text { Bats approach turbines while mating, } \\
\text { feeding, or swarming }\end{array}$ & $\begin{array}{l}\text { Arnett et al. }\left(2008^{\mathrm{\hbar}}, 2011 b^{\delta}\right), \text { Behr et al. }(2007)^{*}, \\
\text { Cryan and Brown }(2007)^{*} \text {, Cryan }(2008)^{\mathrm{h}}, \\
\text { Cryan et al. }(2014)^{*} \text {, Doty and Martin }(2012)^{*} \text { : } \\
\text { insectivorous bats; Grodsky et al. }(2011)^{*}, \\
\text { Horn et al. }(2008)^{*}, \text { Hull and Cawthen }(2013)^{*} \text {, } \\
\text { Redell et al. }(2006)^{\delta} \text {, and Rydell et al. }(2010 \mathrm{a})^{\mathrm{h}}\end{array}$ & Baerwald and Barclay (2011)* (mating) \\
\hline $\begin{array}{l}\text { Open-air foragers with narrow wings more } \\
\text { exposed to collision }\end{array}$ & $\begin{array}{l}\text { Ahlén }(2003)^{\delta} \text {, Doty and Martin }(2012)^{*} \text {, Hull } \\
\text { and Cawthen }(2013)^{*} \text {, and Rydell et al. } \\
\left(2010 \mathrm{a}^{\mathrm{f}}, 2010 \mathrm{~b}^{\mathrm{f}}\right)\end{array}$ & \\
\hline
\end{tabular}


Table 1 continued

\begin{tabular}{|c|c|c|}
\hline Hypothesis & Plausible/supported & Implausible/not-supported \\
\hline \multicolumn{3}{|l|}{ Increased mortality due to attraction } \\
\hline $\begin{array}{l}\text { Investigating turbines as possible tree- } \\
\text { roosts increases collisions risk }\end{array}$ & $\begin{array}{l}\text { Ahlén }(2003)^{\delta} \text {, Cryan and Brown }(2007)^{*} \text {, } \\
\text { Cryan }(2008)^{\mathrm{h}} \text {, Cryan and Barclay }(2009)^{\mathrm{f}} \text {, } \\
\text { Cryan et al. }(2014)^{*} \text {, Hull and Cawthen } \\
(2013)^{*} \text {, and Kunz et al. }(2007)^{\mathrm{f}}\end{array}$ & \\
\hline Attraction due to increased prey availability & $\begin{array}{l}\text { Ahlén }(2003)^{\delta} \text {, Ahlén et al. }(2009)^{*} \text {, Arnett } \\
\text { et al }(2011 \mathrm{~b})^{\delta} \text {, Grodsky et al. }(2012)^{*} \text {, Horn } \\
\text { et al. }(2008)^{*} \text {, Kunz et al. }(2007)^{\mathrm{f}} \text {, and Rydell } \\
\text { et al. }(2010 \mathrm{~b})^{\mathrm{f}}\end{array}$ & $\begin{array}{l}\text { Hull and Cawthen }(2013)^{*} \text { : collision victims } \\
\text { had empty stomachs }\end{array}$ \\
\hline $\begin{array}{l}\text { Bats are attracted to the turbine structure } \\
\text { itself }\end{array}$ & $\begin{array}{l}\text { Ahlén et al. (2009)*, Cryan et al. (2014)*, and } \\
\text { Horn et al. (2008)* }\end{array}$ & \\
\hline Bats are attracted to turbine lighting & $\begin{array}{l}\text { Johnson et al. (2004)*: higher activity but no } \\
\text { difference in mortality rate }\end{array}$ & $\begin{array}{l}\text { Arnett et al. }(2008)^{\mathrm{f}} \text {, Baerwald and Barclay } \\
(2011)^{*} \text {, Horn et al. }(2008)^{*}, \text { Johnson et al. } \\
(2003)^{*} \text {, and Kerns et al. }(2005)^{\delta}\end{array}$ \\
\hline \multicolumn{3}{|c|}{ Increased mortality risk caused by indirect interaction with operating turbines } \\
\hline $\begin{array}{l}\text { Rapid change in air pressure by moving } \\
\text { blades can lead to internal injuries and } \\
\text { accounts for the main cause of fatality } \\
\text { (barotrauma) }\end{array}$ & Baerwald et al. (2008)* & $\begin{array}{l}\text { Grodsky et al. }(2011)^{*} \text {, Houck }(2012)^{\delta} \text {, } \\
\text { Piorkowski and O'Connell }(2010)^{*} \text {, and } \\
\text { Rollins et al. }(2012)^{*}\end{array}$ \\
\hline $\begin{array}{l}\text { Bats caught in vortices increases } \\
\text { probability of collision }\end{array}$ & Horn et al. (2008)* & \\
\hline $\begin{array}{l}\text { Bats caught in vortices can be contorted, } \\
\text { which may result in injury }\end{array}$ & Grodsky et al. (2011)* & \\
\hline
\end{tabular}

Different publication types are indicated: peer-reviewed article $\left({ }^{*}\right)$, peer-reviewed synthesis $\left({ }^{\mathfrak{h}}\right)$, study/report $\left({ }^{\delta}\right)$, conference contribution $\left({ }^{\psi}\right)$

by disturbances of vegetation such as sod damages that in turn enhances habitat quality for those particular species (Pearce-Higgins et al. 2012). Steinborn et al. (2011) observed opposite results for meadow pipits, showing a clear avoidance of the construction site up to $100 \mathrm{~m}$.

\section{Facility-Caused Effects}

Wind turbine design (i.e., tower height, rotor size, tower width) and wind farm layout (i.e., micro-siting) influence birds' perception of an area. While still not well-understood, tall structures like wind turbines can cause habitat loss by avoidance (Walters et al. 2013). Avoidance behavior may result from birds perceiving the vertical structures as potential perches for raptors (Kreuzinger 2008) or birds are simply not familiar with them. Researchers (Barclay et al. 2007; Pearce-Higgins et al. 2012; Stewart et al. 2007) have not been able to prove a strong relationship between the generating capacity and height and number of turbines with behavioral responses. However, turbine heights appear to have a negative impact on the success of habituation (Madsen and Boertmann 2008). Pearce-Higgins et al. (2012) highlight that re-powering of turbines, which involves an increase in turbine height, might cause little additional negative effects on avian species and needs to be observed in the future. Hötker et al. (2006) distinguished breeding birds as less impacted by taller towers, whereas resting birds increase their avoidance distance as height increases. According to Loss et al. (2013), an increased hub height can lead to higher collision rates.

Dürr (2011) found that all collisions with turbine towers happened at facilities with white or gray towers, whereas at towers with a green-colored bottom gradient fading into white or gray upwards, no fatalities occurred. Presumably, an increased visibility for low-flying bird species in contrast to the sky can be the reason. From what we know, no further research has been carried out to understand the impact of tower color on collision probability. Wind farm layout design, defined as micro-siting, can influence impacts on birds. Larsen and Madsen (2000) found decreasing impacts if turbines were arranged linearly or as small clusters, particularly when sited along existing infrastructure like roads. Habitat loss due to the construction of infrastructure associated with wind farms such as access roads cannot be neglected (Larsen and Madsen 2000). However, loss of nesting habitat by wind farm infrastructure can be considered relatively small in comparison to other projects (Zimmerling et al. 2013). McNew et al. (2014) found that greater prairie-chickens (Tympanuchus 
Table 2 Predominant hypotheses on wind energy-induced effects on breeding and resting birds

\begin{tabular}{|c|c|c|}
\hline Hypothesis & Plausible/supported & Implausible/not-supported \\
\hline \multicolumn{3}{|l|}{ Construction effects } \\
\hline Displacement of birds during construction & $\begin{array}{l}\text { Drewitt and Langston }(2006)^{\mathrm{f}} \text {, Pearce-Higgins } \\
\text { et al. }(2012)^{*} \text {, and Steinborn et al. }(2011)^{\delta}\end{array}$ & $\begin{array}{l}\text { Pearce-Higgins et al. (2012)*, and Steinborn } \\
\text { et al. }(2011)^{\delta}\end{array}$ \\
\hline \multicolumn{3}{|l|}{ Facility-caused effects } \\
\hline $\begin{array}{l}\text { Increased turbine height increases effects } \\
\text { (displacement, collision risk) }\end{array}$ & Hötker $(2006)^{\delta}$ (displacement of resting birds) & $\begin{array}{l}\text { Barclay et al. }(2007)^{*} \text {, Everaert }(2014)^{*} \text {, } \\
\text { Hötker }(2006)^{\delta} \text { (breeding birds); Pearce- } \\
\text { Higgins et al. }(2012)^{*} \text {, and Stewart et al. } \\
(2007)^{\mathrm{f}}\end{array}$ \\
\hline
\end{tabular}

Spatial turbine layout limits effects on birds Larsen and Madsen (2000**

if arranged in lines or small clusters

Operation effects

Resting species show avoidance behavior near turbines

Devereux et al. (2008)* (common pheasant), Fijn et al. (2012)*, Hötker et al. $(2005)^{\delta}$, Steinborn et al. $(2011)^{\delta}$, and Stevens et al. (2013)*

Breeding densities increase with increasing distance to turbines

Leddy et al. (1999)*, Pearce-Higgins et al. (2009)*, Winder et al. (2014)*, and Zeiler and Gruenschachner-Berger (2009)*

Wind farms cause no effects on breeding success

Decrease in comfort behavior of some species near turbines

Birds adapt to wind farms and show signs of Madsen and Boertmann (2008)* habituation

Reichenbach and Steinborn $(2006)^{\delta}$

Steinborn et al. $(2011)^{\delta}$

Enhanced effects due to species characteristics

Resting birds are more sensitive to wind

Hötker et al. (2005) $)^{\delta}$, Reichenbach and turbines than breeding birds (avoidance)

Collision risk is species-specific

Steinborn (2006) ${ }^{\delta}$, and Steinborn et al. $(2011)^{\delta}$

Drewitt and Langston (2006) $)^{\mathrm{h}}$, Everaert (2014)*, Grünkorn et al. (2009)*, Gue et al. (2013)*, and Morinha et al. (2014)*

Minor risk of collision for species that spend most of the time on the ground (in particular Galliformes)/outside the rotor swept zone

Brennan et al. (2009) $)^{\psi}$, Gue et al. (2013)*, LeBeau et al. (2014)*, Pruett et al. (2009b)*, Sandercock et al. (2013) $)^{\delta}$, and Winder et al. (2013)*

Species show no avoidance behavior during flight

Pearce-Higgins et al. (2009)* and Steinborn et al. $(2011)^{\delta}$

Displacement is species-specific

Devereux et al. (2008)*, Pearce-Higgins et al. (2009)*, and Stevens et al. (2013)*

Inter-annual dynamics in reaction to wind turbines

Fijn et al. (2012)* and Morinha et al. (2014)*

Decrease in predation risk due to impacts of Winder et al. (2013)*

wind turbines on predators (e.g., collision)

Species that commute between two habitats (e. g., resting and foraging) are at higher collision and displacement risk

Drewitt and Langston (2006) $)^{\mathrm{f}}$, Hötker et al. $(2005)^{\delta}$, Langgemach and Dürr (2013) $)^{\delta}$, and Pearce-Higgins et al. (2008)*

Enhanced effects due to spatial/site characteristics
Land use can have higher impacts on breeding bird abundances than wind
Steinborn et al. $(2011)^{\delta}$ and Steinborn and Reichenbach (2012)* turbines

The less disturbed a natural habitat, the higher the effects on birds by wind farms

Larsen and Madsen (2000)*, Pearce-Higgins et al. $(2009)^{*}$, and Steinborn et al. $(2011)^{\delta}$

Hötker et al. (2005) ${ }^{\delta}$ and Rydell et al. (2012) ${ }^{\mathrm{f}}$

Devereux et al. (2008)* and Stevens et al. (2013)*

Douglas et al. (2011)*, de Lucas et al. $(2005)^{*}$, Steinborn et al. $(2011)^{\delta}$, and Steinborn and Reichenbach (2012)*

Falkdalen Lindahl et al. $(2013)^{\psi}$

Fijn et al. (2012)* and Everaert (2014)*

Sandercock et al. $(2013)^{\delta}$

Different publication types are indicated: peer-reviewed article $\left(^{*}\right)$, peer-reviewed synthesis $\left(^{(\mathfrak{i})}\right.$, study/ report $\left({ }^{\delta}\right)$, and conference contribution $\left({ }^{\psi}\right)$ 
cupido) chose nest sites dependent on the local land management rather than on the wind farm infrastructure.

\section{Operation Effects}

With minimal space consumption, wind turbines do not cause substantial habitat loss. However, they can trigger disturbance or displacement. Such avoidance behavior can affect feeding or roosting habitats, resulting in a shift to sub-optimal habitat (Rees 2012). Devereux et al. (2008) reported that the majority of wintering farmland birds in the UK are most likely not affected by operational wind turbines. They showed no sign of avoidance behavior but the larger and less maneuverable species such as the common pheasant (Phasianus colchicus) were less abundant near turbines, indicating avoidance response.

A grassland study on passerines carried out in the U.S. found higher breeding densities in areas located at least $180 \mathrm{~m}$ away from turbines (Leddy et al. 1999). PearceHiggins et al. (2009) compared data from 12 upland wind farms in the UK, coming to a similar conclusion that some species (seven out of 12), such as the golden plover (Pluvialis apricaria), common snipe (Gallinago gallinago), and wheatear (Oenanthe oenanthe), showed significant avoidance of turbines as well as access roads. Depending on the species, avoidance can range from 100 to $800 \mathrm{~m}$, leading to a reduction of breeding density up to ca. $50 \%$. This could not be supported by the findings of Douglas et al. (2011) who found no significant avoidance of the turbines by golden plovers at the same site. They concluded that the operation of wind farms may not necessarily cause a reduction in bird populations. Other authors (e.g., de Lucas et al. 2005; Steinborn and Reichenbach 2012) agreed, given that they were able to verify neither affected population levels of birds (in particular passerines and waders) nor negative impacts on the breeding success (Reichenbach and Steinborn 2006). Steinborn et al. (2011) observed that curlews (Numenius arquata) limited their comfort behavior (resting or grooming/cleaning) in close range to turbines.

\section{Inter-annual Dynamics and Species-Specificity}

Wind energy-induced effects on birds depend, among other factors, on species behavior and their particular use of habitat (e.g., resting, breeding). Some authors (Hötker et al. 2005; Reichenbach and Steinborn 2006) stated that impacts on resting birds can be more severe than on breeding birds. However, unlike the effect on breeding birds that are bound to their nest, the impact on resting birds might be reduced due to their use of alternative sites or foraging areas, if available. This can be a coping mechanism to avoid wind farms to an extent (Kreuzinger 2008), but it can also be perceived as small-scale displacement (Steinborn et al. 2011).

Grünkorn et al. (2009) collected data on collision rates along the German northwest coast with predominant fatalities of high abundant gulls and waders. Other authors (Zimmerling et al. 2013) observed similar results in Canada and particularly detected carcasses of abundant species with large populations, such as the horned lark (Eremophila alpestris), golden-crowned kinglet (Regulus satrapa), or red-eyed vireo (Vireo olivaceus). The authors concluded that for most species, population level effects are unlikely because species that showed high collision rates (e.g., passerines) had large population sizes (Zimmerling et al. 2013). The species that show high collision rates showed no obvious signs of avoidance (Grünkorn et al. 2009). Nocturnal species or fast-flying species like ducks seem to have a lower avoidance behavior and relatively high fatality rates (Grünkorn 2013). However, this does not certainly apply for all ducks, as collision rates vary among species and their behavior. Gue et al. (2013) observed no collisions for blue-winged teals (Anas discors) but reported a collision of one mallard (Anas platyrhynchos). The authors explain this with a smaller home range of bluewinged teals and their rather non-hazardous flight height (Gue et al. 2013).

For species that spend most of their lives on the ground such as the grouse, it is not likely that they collide with the rotating turbine blades, simply based on their life strategy (Brennan et al. 2009; Pruett et al. 2009b). This has been confirmed for greater prairie-chickens (Tympanuchus cupido) which did not reveal high collision rates, while the majority of fatalities were caused by predators (Winder et al. 2013). Due to flight behavior at low altitudes, collisions with the tower structure instead of the turbine blades are more probable and have been witnessed for the red grouse (Lagopus lagopus scoticus) in Sweden (Falkdalen et al. 2013) and black grouse (Tetrao tetrix) in Austria (Zeiler and Gruenschachner-Berger 2009). Pruett et al. (2009a) raised the question whether species like grouses, choosing habitats with little or no vertical structures, might be scared by anthropogenic towers due to a perceived threat of raptor perches. Avoidance has also been observed in Austria for black grouses, moving farther away from the turbines.

A barrier effect of wind turbines can become relevant for resting and breeding species during migration, as their foraging and resting grounds can be blocked. Daily migrating species that pass wind farms more frequently such as geese, waders, and common cranes (Grus grus) (Hötker et al. 2005) are of higher concern. Another example of a breeding species at risk is the black stork (Ciconia nigra), which can fly up to $20 \mathrm{~km}$ between nesting and foraging grounds, likely resulting in alteration of flight paths 
Table 3 Predominant hypotheses on wind energy-induced effects on raptors

\begin{tabular}{|c|c|c|}
\hline Hypothesis & Plausible/supported & Implausible/not-supported \\
\hline \multicolumn{3}{|l|}{ Increased collision risk due to raptor abundance } \\
\hline $\begin{array}{l}\text { High raptor abundance increases collision } \\
\text { risk }\end{array}$ & $\begin{array}{l}\text { Barrios and Rodríguez (2004)*, Carrete et al. (2012)*, } \\
\text { Smallwood et al. (2009)*, and Martínez-Abraín et al. } \\
(2012)^{*}\end{array}$ & $\begin{array}{l}\text { Garvin et al. (2011)*, de Lucas et al. } \\
(2008)^{*} \text {, and Whitfield and Madders } \\
(2006)^{\mathrm{h}}\end{array}$ \\
\hline $\begin{array}{l}\text { High abundance on flight paths following } \\
\text { areas with major wind currents (depending } \\
\text { on topography and weather) }\end{array}$ & $\begin{array}{l}\text { Barrios and Rodríguez (2004)*, Katzner et al. } \\
(2012)^{*} \text {, de Lucas et al. }(2012 \mathrm{~b})^{*} \text {, and Hoover } \\
(2002)^{\delta}\end{array}$ & \\
\hline $\begin{array}{l}\text { High abundance on flight paths following } \\
\text { linear landscape features (e.g., ridges, } \\
\text { cliffs, canyons) }\end{array}$ & $\begin{array}{l}\text { Katzner et al. (2012)* and Smallwood et al. (2007)*: } \\
\text { borrowing owl }\end{array}$ & \\
\hline \multicolumn{3}{|c|}{ Increased collision risk due to flight behavior and activity } \\
\hline $\begin{array}{l}\text { Increased flight activity with decrease in } \\
\text { turbine-aerie distance/ breeding site } \\
\text { increases collision risk }\end{array}$ & $\begin{array}{l}\text { Bevanger et al. }(2010)^{\delta} \text {, Eichhorn et al. }(2012)^{*} \text {, and } \\
\text { Smallwood et al. }(2007)^{*} \text { : borrowing owl }\end{array}$ & Carrete et al. (2012)* \\
\hline Repeated fly-bys increase collision risk & Katzner et al. $(2012)^{*}$ and Ledec et al. $(2011)^{\delta}$ & \\
\hline $\begin{array}{l}\text { Search/foraging flight within rotor swept } \\
\text { zone increases collision risk }\end{array}$ & $\begin{array}{l}\text { Dahl et al. }(2013)^{*} \text {, Ledec et al. }(2011)^{\delta} \text {, Mammen } \\
\text { et al. }(2011)^{\psi} \text {, Martínez-Abraín et al. }(2012)^{*} \text {, and } \\
\text { Smallwood and Thelander }\left(2004^{\delta}, 2008^{*}\right)\end{array}$ & \\
\hline $\begin{array}{l}\text { Local populations at greater risk than } \\
\text { migrants due to flight behavior (e.g., } \\
\text { foraging, fly-bys) }\end{array}$ & $\begin{array}{l}\text { Barrios and Rodríguez (2004)* and Katzner et al. } \\
(2012)^{*}\end{array}$ & $\begin{array}{l}\text { Smallwood et al. (2007)*: borrowing } \\
\text { owl }\end{array}$ \\
\hline Seasonal behavior influences flight activity & $\begin{array}{l}\text { Barrios and Rodríguez (2004)*, Camiña }(2011)^{\psi} \text {, } \\
\text { May et al. }(2011)^{\delta} \text {, and Smallwood et al. (2009)* }\end{array}$ & \\
\hline $\begin{array}{l}\text { Species-specific high-risk flight behavior (e. } \\
\text { g., circular flight, foraging strategy) } \\
\text { increases collision risk }\end{array}$ & $\begin{array}{l}\text { Garvin et al. (2011)*, Hull and Muir (2013)*, de } \\
\text { Lucas et al. }(2008)^{*} \text {, and Smallwood et al. (2009)* }\end{array}$ & \\
\hline \multicolumn{3}{|c|}{ Increased collision risk due to site and season characteristics } \\
\hline $\begin{array}{l}\text { Low flight altitude near summits and steep } \\
\text { slopes increases collision risk }\end{array}$ & $\begin{array}{l}\text { Barrios and Rodríguez }(2004)^{*} \text {, de Lucas et al. } \\
(2012 b)^{*} \text {, Camiña }(2011)^{\psi} \text {, Hoover }(2002)^{\delta} \text {, } \\
\text { Katzner et al. (2012)*, Muños Gallego et al. } \\
(2011)^{\psi} \text {, and Orloff and Flannery }(1992)^{\delta}\end{array}$ & \\
\hline $\begin{array}{l}\text { Low flight altitude with low air temperature } \\
\text { increases collision risk }\end{array}$ & $\begin{array}{l}\text { Barrios and Rodríguez }(2004)^{*} \text {, Camiña }(2011)^{\psi} \text {, } \\
\text { and Katzner et al. }(2012)^{*}\end{array}$ & \\
\hline $\begin{array}{l}\text { Raptors drawn to wind farm due to low } \\
\text { vegetation cover/open landscapes } \\
\text { (favorable hunting ground) increases } \\
\text { collision risk }\end{array}$ & $\begin{array}{l}\text { Bellebaum et al. (2013)*, Dürr (2009) }{ }^{\delta} \text {, Mammen } \\
\text { et al. }(2011)^{\psi} \text {, and Smallwood et al. (2007)*: } \\
\text { borrowing owls }\end{array}$ & \\
\hline \multicolumn{3}{|l|}{ Avoidance } \\
\hline $\begin{array}{l}\text { Raptors show no avoidance behavior and } \\
\text { exposes them to greater risk of collision }\end{array}$ & $\begin{array}{l}\text { Bevanger et al. }(2010)^{\delta}, \text { Dahl et al. }(2013)^{*} \text {, } \\
\text { Mammen et al. }(2011)^{\psi} \text {, and Smallwood and } \\
\text { Thelander }(2004)^{\delta}\end{array}$ & $\begin{array}{l}\text { Garvin et al. (2011)*; Hull and Muir } \\
\text { (2013)*; de Lucas et al. (2004)* }\end{array}$ \\
\hline $\begin{array}{l}\text { Low maneuverability due to flight type and } \\
\text { morphology increases collision risk }\end{array}$ & $\begin{array}{l}\text { Baisner et al. (2010)*, Barrios and Rodríguez (2004)*, } \\
\text { Dahl et al. (2013)*, Katzner et al. (2012)*, and } \\
\text { Smallwood and Thelander (2004) }\end{array}$ & \\
\hline $\begin{array}{l}\text { Low rotation speed and/or sparse distribution } \\
\text { of turbines decreases avoidance response }\end{array}$ & $\begin{array}{l}\text { Hull and Muir (2013)*: hub speed and Smallwood } \\
\text { et al. (2007)*: borrowing owl }\end{array}$ & Orloff and Flannery $(1992)^{\delta}$ \\
\hline $\begin{array}{l}\text { Attraction due to increase in food } \\
\text { availability/change in food distribution } \\
\text { increases collision risk }\end{array}$ & $\begin{array}{l}\text { Dürr (2009) }{ }^{\delta} \text {, Camiña }(2011)^{\psi} \text {, and Smallwood et al. } \\
(2007)^{*} \text { : borrowing owl }\end{array}$ & Hoover $(2002)^{\delta}$ \\
\hline $\begin{array}{l}\text { Inattentiveness during foraging increases risk } \\
\text { of collision }\end{array}$ & $\begin{array}{l}\text { Orloff and Flannery }(1992)^{\delta} \text { and Smallwood et al. } \\
(2009)^{*}\end{array}$ & \\
\hline
\end{tabular}


Table 3 continued

\begin{tabular}{|c|c|c|}
\hline Hypothesis & Plausible/supported & Implausible/not-supported \\
\hline $\begin{array}{l}\text { Inattentiveness due to interaction behavior } \\
\text { increases risk of collision }\end{array}$ & $\begin{array}{l}\text { Dahl et al. }(2013)^{*} \text {, May et al. }\left(2010^{\delta}, 2011^{\delta}\right) \text {, } \\
\text { Smallwood et al. }(2009)^{*}\end{array}$ & \\
\hline $\begin{array}{l}\text { Higher risk of collision for adults than sub- } \\
\text { adults }\end{array}$ & $\begin{array}{l}\text { Bellebaum et al. (2013)*, Bevanger et al. }(2010)^{\delta} \text {, } \\
\text { Camiña }(2011)^{\psi}: \text { Northern Spain; in Dahl et al. } \\
(2013) \text {, and May et al. }\left(2010^{\delta}, 2011\right)^{\delta}: \text { due to } \\
\text { higher involvement in social behavior }\end{array}$ & $\begin{array}{l}\text { Dahl et al. (2013)*: due to higher } \\
\text { abundance within wind farm; de Lucas } \\
\text { et al. }(2012 a)^{*} \text {, Powlesland }(2009)^{\delta}\end{array}$ \\
\hline \multicolumn{3}{|l|}{ Indirect effects from wind energy development } \\
\hline $\begin{array}{l}\text { Decrease in breeding attempts/ success due to } \\
\text { turbine-induced adult collision risk }\end{array}$ & $\begin{array}{l}\text { Bellebaum et al. }(2013)^{*} \text {, Bevanger et al }(2010)^{\delta} \text { : } \\
\text { territorial shift, Dahl et al. }(2012)^{*} \text {, and Martínez- } \\
\text { Abraín et al. }(2012)^{*}\end{array}$ & \\
\hline Displacement during operation & $\begin{array}{l}\text { Garvin et al. (2011)* and de Lucas et al. (2004)* } \\
\text { (except Falco tinnunculus) }\end{array}$ & $\begin{array}{l}\text { Dahl et al. (2013)*, Hull and Muir } \\
(2013)^{*} \text {, and Madders and Whitfield } \\
(2006)^{\mathrm{f}}\end{array}$ \\
\hline
\end{tabular}

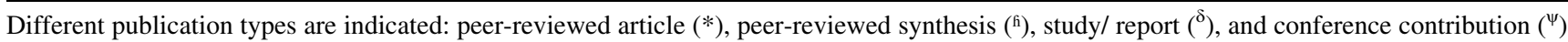

(Langgemach and Dürr 2013). However, these effects on birds, possibly resulting in higher energy consumption or injuries as a result of collision, are not yet well known. Avoidance during flight has been documented for gulls, Bewick's swans (Cygnus bewickii), and lapwings (Vanellus vanellus) (Everaert 2014; Fijn et al. 2012; Steinborn et al. 2011) but for other species no avoidance of single turbines (micro-avoidance) has been observed (Pearce-Higgins et al. 2009; Steinborn et al. 2011).

Fijn et al. (2012) stated that Bewick's swans (Cygnus bewickii) preferred areas farther away from wind turbines, but with decreasing food availability during the year, they tended to move closer to the facilities, showing signs of intra-annual behavioral change. Individuals of the same taxa can show different behavior depending on their lifestage, which was shown for lapwings (Vanellus vanellus) in Steinborn et al. (2011). Furthermore, an increased collision risk can exist for species that show characteristic gender behavior, e.g., the male song-flights of skylarks (Alauda arvensis) (Morinha et al. 2014).

\section{Site-Specific Effects}

Factors including inter-annual dynamics and site-specificity can shape study outcomes, delivering contradictory results. Pearce-Higgins et al. (2009), for example, classified breeding curlew populations (Numenius arquata) as particularly vulnerable with an avoidance distance of up to $800 \mathrm{~m}$ distance. Reichenbach and Steinborn (2006) and Steinborn et al. (2011) found a considerably lower distance of $50 \mathrm{~m}$. Steinborn et al. (2011) concluded that other parameters (i.e., land use) had higher impacts on the abundance of birds than the distance to wind turbines. Pearce-Higgins et al. (2009) took this even further by assuming that habitat conditions (semi-natural vs. intensive production) can have an influence on the avoidance distance; the more natural, the more sensitive the species. Furthermore Douglas et al. (2011) hypothesize that weather conditions and resulting prey availability might explain changes in breeding abundances that do not immediately result from wind turbines.

Many factors such as non-standardized methodologies (Pearce-Higgins et al. 2012), a lack of statistical comparability, and ongoing habitat and land use changes in a study area influence study results. Most studies were carried out short-timed with sample periods of 1-3 years, while only long-term studies could detect some effects (Madsen and Boertmann 2008). An example is the avoidance behavior of skylarks (Alauda arvensis) in Germany that could not be observed until several years subsequent to wind farm construction (Steinborn et al. 2011). Madsen and Boertmann (2008) investigated pink-footed geese (Anser brachyrhynchus) which over time reduced their distances to the turbines and started foraging between the facilities (10-year study period). The authors understood this as habituation to the wind turbines. On the other hand, further wind energy development might lead to significant cumulative impacts on bird populations, as Pearce-Higgins et al. (2008) presumed for regional golden plover (Pluvialis apricaria) populations.

\section{Raptors}

Various studies have shown raptors to be especially vulnerable to collision with wind turbines (e.g., Baisner et al. 2010; Dahl et al. 2013; Ledec et al. 2011; de Lucas et al. 2012b; Madders and Whitfield 2006; Martínez-Abraín et al. 2012; Smallwood and Thelander 2004, 2008). However, Ledec et al. (2011) synthesized that other studies from Europe (Dürr 2003; Hötker et al. 2006; 
Percival 2003) reported relatively low fatality rates. According to Erickson et al. (2002), only $2 \%$ of the reported bird fatalities in the U.S., excluding California, had been diurnal raptors. Even though raptor fatality rates appear to be relatively low in comparison to other groups such as passerines (e.g., Aumüller et al. 2011), they are considered to be among the most vulnerable species groups in the context of wind energy. Being long-lived and slow reproducers makes it difficult to out-balance additional mortality (Bellebaum et al. 2013; Dahl et al. 2012; Katzner et al. 2012; Ledec et al. 2011). The reason why raptors are prone to collision with wind turbines is most likely a complex compound of site-species-season-specific factors outlined in Table 3.

\section{Raptor Abundance and Flight Activity}

According to some authors, high collision risk most likely occurs in times and locations where raptors are most abundant (Barrios and Rodríguez 2004; Carrete et al. 2012; Martínez-Abraín et al. 2012; Smallwood et al. 2009). Flight corridors following linear topographic features and major wind currents (Katzner et al. 2012; de Lucas et al. 2012b), areas within foraging habitat (Martínez-Abraín et al. 2012), and breeding grounds (Bevanger et al. 2010; Eichhorn et al. 2012) have been identified as sites of high flight abundance and activity in numerous studies. Eichhorn et al. (2012) stated that based on a validated model, collision risk decreased exponentially with an increase in turbine-aerie distance, which could not be verified by Carrete et al. (2012). Other authors did not find a correlation between raptor abundance and mortality at all (Garvin et al. 2011; de Lucas et al. 2008).

\section{Flight Behavior and Maneuverability}

Repeated raptor fly-bys, due to circling and soaring flights, cause interaction with wind turbines disproportionally often (Katzner et al. 2012; Ledec et al. 2011). Birds of prey spend much time flying within the rotor swept area during foraging and search flights (Smallwood and Thelander 2004). Due to their large size and heavy wing-load, raptors are soaring and gliding $>95 \%$ of their time in flight and show almost no flapping flight in order to reduce energy consumption (Spaar 1997 in Dahl et al. 2013). However, using this flight type makes them less maneuverable (Baisner et al. 2010; Smallwood and Thelander 2004) and more dependent on weather conditions, especially on wind currents and updrafts influenced by the topography and air temperature in the vicinity of the turbines (Camiña 2011; Hoover 2002; Katzner et al. 2012). This indicates, on the one hand, that collision risk might be higher when temperature is low due to relatively weak thermal uplifts. On the other hand, risk of collision also increases in areas near slopes and summits when raptors use orographic uplifts. In both situations, raptors are forced to fly at lower altitudes and therefore closer to the moving turbine blades (Camiña 2011; Katzner et al. 2012). Additionally, Katzner et al. (2012) stated that due to a constantly lower flight altitude, regardless of the prevailing topography and differences in flight behavior such as foraging and perching, individuals of local populations might be at greater risk of collision than migratory raptors (Katzner et al. 2012).

\section{Seasonal Flight Behavior}

Flight activity, thus most likely collision risk, is influenced by seasonal behavior (Barrios and Rodríguez 2004; Camiña 2011; Carrete et al. 2012) and inter-annual differences in local abundance (Carrete et al. 2012). According to Camiña (2011), flight activity likely decreases during breeding season, whereas an increase during hatching, migration departure, and pair-bonding might be observed (Camiña 2011). This has also been supported by Dürr (2009) at times when frequent foraging flights are needed to feed nestlings. Barrios and Rodríguez (2004) and (de Lucas et al. 2008) reported an increase in mortality during autumn/winter, with birds flying closer to the operating turbines (Barrios and Rodríguez 2004). Smallwood et al. (2007) also observed a peak in fatality during fall and early winter at Altamont Pass during migration activity. In contrast, a peak in flight activity of white-tailed eagles (Haliaeetus albicilla) could be observed during breeding season within the Smøla wind farm in Norway, and when the majority of collisions of adult individuals occurred (Bevanger et al. 2010).

\section{Food Availability and Foraging Behavior}

Wind farms are often located within open agricultural landscapes with low vegetation cover, which are considered favorable hunting habitats for raptors (Bellebaum et al. 2013; Dürr 2009; Mammen et al. 2011). Wind farms might increase prey availability in the close vicinity of the turbines, drawing raptors inside the wind farm area (Smallwood et al. 2007). Cattle gathered and spent much of their time close to the base of the turbines, introducing nutrient-rich substance which likely led to an increased abundance of prey species (e.g., grasshoppers, lizards). Smallwood et al. (2007) further observed the highest mortality of borrowing owls where the density of ground squirrel borrows (Spermophilus beecheyi) was highest within $15 \mathrm{~m}$ distance from the turbine base. Additionally, they reported owls spending disproportionally more time flying close to turbines in areas of intermittent rodent control (Smallwood et al. 2007). The study from 
Smallwood and Thelander (2004) described that rock piles remained within the wind farm area after construction and were inhabited by ground squirrels and desert cottontails (Sylvilagus audubonii), likely increasing food availability inside the wind farm. Besides more time spent near turbines, raptors might be inattentive while focusing on their prey, exposing themselves at greater risk of collision (Orloff and Flannery 1992; Smallwood et al. 2009).

\section{Intra- and Inter-specific Interaction}

Intra-specific and inter-specific interactions may also result in a decrease in vigilance, differing seasonally, especially among adults being more involved in social behavior compared to sub-adults (Dahl et al. 2013: May et al. 2010, 2011; Smallwood et al. 2009). Bellebaum et al. (2013) reported that mainly adults were found killed, and is supported by the findings of Camiña (2011). According to a study from Northern Spain, $75 \%$ of the mortalities were adults. In contrast, a study in Tarifa, Spain revealed an adverse trend with ca. $75 \%$ being juveniles (de Lucas et al. 2012a). Dahl et al. (2013) observed more sub-adults within the wind farm area than outside, from where territorial adults were chasing them away, increasing their collision risk (also Smallwood et al. 2009). Moreover, sub-adults might be more prone to collision, due to a lack of experience and poorer flying skills (Powlesland 2009).

\section{Avoidance Response}

Researchers disagree on whether raptors actively avoid areas with wind turbines. While Dahl et al. (2013) and Bevanger et al. (2010) reported the same activities inside the wind farm as in the control area, indicating no sign of avoidance response, other studies observed extensive avoidance of wind turbines triggered by visual recognition (Garvin et al. 2011; Hull and Muir 2013). Smallwood and Thelander (2004) stated that raptors might even be attracted to the immediate proximity of the turbines.

In a study carried out in Tasmania (Hull and Muir 2013), it was witnessed that raptors were passing approximately halfway through the space between the facilities, indicating complete awareness of the turbine presence. Furthermore, wedge-tailed eagles (Aquila audax) and white-bellied sea-eagles (Haliaeetus leucogaster) even adapted their avoidance behavior in relation to the wind farm's development stage (control site compared to testing stage, when turbines were not fully operational and also compared to the operational stage). Additionally, an increase in avoidance behavior could be observed in rainy weather with strong winds among wedge-tailed eagles, but not for white-bellied seaeagles (Hull and Muir 2013). Smallwood et al. (2009) stated that birds spent less time flying when wind speed increased; however, those raptors that still flew during those conditions acted even closer to the turbines, being less maneuverable and therefore exposed to greater risk. In other studies, avoidance decreased with less rotation speed and lower density in turbine distribution, causing raptors to pass more frequently through gaps in turbine rows (Smallwood and Thelander 2004; Smallwood et al. 2007). This indicates turbine-specific mortality rates, likely influenced by turbine surroundings (Camiña 2011; Hoover 2002; Hull and Muir 2013; de Lucas et al. 2012a, 2012b; Smallwood et al. 2007), turbine activity, and possibly by turbine design (Hull and Muir 2013; Smallwood and Thelander 2004; Smallwood et al. 2007).

Moreover, avoidance behavior appears to be speciesspecific (e.g., Garvin et al. 2011). Garvin et al. (2011) revealed that most raptor species showed high avoidance behavior. In fact, only the red-tailed hawk (Buteo jamaicensis) was found dead within the study period. Together with the observed population of the turkey vulture (Cathartes aura), this species had shown high-risk flight behavior and relatively low avoidance behavior.

\section{Displacement and Habitat Loss}

Displacement might cause a decrease in raptor abundance (Garvin et al. 2011; Walker et al. 2005 in Hull and Muir 2013) and breeding density (Dahl et al. 2012). However, Hull and Muir (2013) and Madders and Whitfield (2006) did not report significant displacement, nor did Dahl et al. (2013) observe a significant difference in flight activity inside and outside the wind farm. This discrepancy might be explained by a species- and site-specific response to the construction and presence of a wind farm (Hull and Muir 2013). de Lucas et al. (2004) could not identify any change in abundance from the pre- to post-construction period with the exception of the common kestrel (Falco tinnunculus). The latter, however, might be related to a difference in vegetation cover. According to Powlesland (2009), the displacement effect on the New Zealand falcon (Falco novaeseelandiae) is most likely very low. This might be due to the species' high habitat adaptability. However, if a wind farm is constructed close to a nest site, nest abandonment can occur and effects on population level can therefore not be ruled out (Madders and Whitefield 2006; Powlesland 2009).

\section{Possible Long-Term and Cumulative Effects}

de Lucas et al. (2004) hypothesized that habituation to the presence of turbines might be possible, which at the same 
Table 4 Predominant hypotheses on wind energy-induced effects on migratory birds offshore

\begin{tabular}{|c|c|c|c|}
\hline \multicolumn{2}{|l|}{ Hypotheses } & Plausible/supported & $\begin{array}{l}\text { Implausible/not- } \\
\text { supported }\end{array}$ \\
\hline \multicolumn{4}{|c|}{ Increase of potential collision risk } \\
\hline \multirow[t]{3}{*}{$\begin{array}{l}\text { Times of high bird } \\
\text { abundance }\end{array}$} & $\begin{array}{l}\text { Migration peaks in spring and } \\
\text { autumn }\end{array}$ & $\begin{array}{l}\text { Hein et al. (2011a)*, Hill et al. (2014) })^{\delta} \text {, Hüppop et al. } \\
\left(2004^{*}, 2006^{*}\right) \text {, and van de Laar }(2007)^{\delta} \text { : gas platform }\end{array}$ & \\
\hline & $\begin{array}{l}\text { Majority: nocturnal migrants } \\
\text { (esp. songbirds, ducks) }\end{array}$ & $\begin{array}{l}\text { Aumüller et al. }(2011)^{*} \text {, Christensen et al. }(2004)^{\delta} \text {, } \\
\text { Hill et al. }(2014)^{\delta} \text {, and Hüppop et al. }\left(2004^{*}, 2012^{*}\right)\end{array}$ & $\begin{array}{l}\text { Plonczkier and Simms } \\
(2012)^{*}: \text { pink-footed } \\
\text { geese }\end{array}$ \\
\hline & $\begin{array}{l}\text { Few mass migration events per } \\
\text { year }\end{array}$ & $\begin{array}{l}\text { Aumüller et al. (2011)*, Hüppop et al. (2004*, 2006*, } \\
\left.2012^{*}\right) \text {, and Nilsson et al. (2006)*: blue tit }\end{array}$ & \\
\hline \multirow[t]{5}{*}{$\begin{array}{l}\text { Weather patterns in } \\
\text { departure area } \\
\text { trigger migration } \\
\text { activity }\end{array}$} & Tailwinds & $\begin{array}{l}\text { Aumüller et al. (2011)*, Hüppop et al. (2004*, } \\
\text { 2006*), Nilsson et al. (2006)*, Pettersson and } \\
\text { Fågelvind }(2011)^{\delta} \text {, and Plonczkier and Simms } \\
(2012)^{*}\end{array}$ & $\begin{array}{l}\text { Nilsson et al. (2006)*: } \\
\text { regular migrants less } \\
\text { influenced then partial }\end{array}$ \\
\hline & Low cloud cover & $\begin{array}{l}\text { Nilsson et al. (2006)*: blue tit, and Plonczkier and } \\
\text { Simms (2012)* }\end{array}$ & \\
\hline & Low precipitation & $\begin{array}{l}\text { Hüppop et al. (2004)*, Nilsson et al. (2006)*: blue tit, } \\
\text { and Pettersson }(2005)^{\delta}\end{array}$ & \\
\hline & Atmospheric pressure/change & $\begin{array}{l}\text { Hein et al. (2011a)* and Shamoun-Baranes et al. } \\
\text { (2006)* }\end{array}$ & \\
\hline & Temperature & Hüppop and Winkel (2006)*: pied flycatcher & \\
\hline \multirow[t]{2}{*}{$\begin{array}{l}\text { Areas of high } \\
\text { abundance }\end{array}$} & Migration corridors & $\begin{array}{l}\text { Aschwanden et al. }(2011)^{\delta} \text { (onshore study); } \\
\text { Pettersson and Fågelvind }(2011)^{\delta} \text {, and Reichenbach } \\
\text { and Grünkorn }(2011)^{\delta}\end{array}$ & \\
\hline & Near coastlines & $\begin{array}{l}\text { Burger et al. }(2012)^{*} \text {, Hüppop et al. }\left(2004^{*}, 2006^{*}\right) \text {, } \\
\text { Kahlert et al. }(2011)^{\delta} \text {, and Stienen et al. }(2007)^{*}\end{array}$ & \\
\hline Reverse migration & Repeated fly-bys & Hüppop et al. (2006)* & \\
\hline \multirow[t]{2}{*}{ Low maneuverability } & $\begin{array}{l}\text { Species-specific flight ability } \\
\text { resulting from morphology }\end{array}$ & $\begin{array}{l}\text { Furness et al. (2013)*, Garthe and Hüppop (2004)*, } \\
\text { and Plonczkier and Simms (2012)* }\end{array}$ & \\
\hline & Experience of bird & Hüppop et al. (2006)* & \\
\hline \multirow[t]{3}{*}{ Low flight altitude } & Species-specific flight altitude & $\begin{array}{l}\text { Furness et al. (2013)*, Hüppop et al. (2004*, 2006*), } \\
\text { and Pettersson and Fågelvind }(2011)^{\delta}\end{array}$ & \\
\hline & Time of the day and year & $\begin{array}{l}\text { Hüppop et al. (2004)*: afternoon, 2. half of night and } \\
\text { spring, and Pettersson and Fågelvind }(2011)^{\delta}: \\
\text { during day and spring }\end{array}$ & \\
\hline & $\begin{array}{l}\text { Migration distance and flight } \\
\text { experience }\end{array}$ & Hüppop et al. (2006)* & \\
\hline \multirow[t]{2}{*}{$\begin{array}{l}\text { Decrease in flight } \\
\text { altitude }\end{array}$} & Low visibility & $\begin{array}{l}\text { Aumüller et al. (2011)*, Hüppop et al. (2006)*, and } \\
\text { Plonczkier and Simms (2012)* }\end{array}$ & $\begin{array}{l}\text { Pettersson and Fågelvind } \\
(2011)^{\delta} \text { : fly above fog }\end{array}$ \\
\hline & $\begin{array}{l}\text { Rapid change in weather } \\
\text { conditions (precipitation, } \\
\text { headwind, strong winds) }\end{array}$ & $\begin{array}{l}\text { Aumüller et al. (2011)*, Hüppop et al. (2004*, } \\
\text { 2006*), Pettersson and Fågelvind }(2011)^{\delta} \text {, and } \\
\text { Reichenbach and Grünkorn }(2011)^{\delta}\end{array}$ & \\
\hline \multirow[t]{4}{*}{$\begin{array}{l}\text { Attraction to artificial } \\
\text { light sources }\end{array}$} & $\begin{array}{l}\text { Adverse weather condition with } \\
\text { low visibility }\end{array}$ & $\begin{array}{l}\text { Aumüller et al. }(2011)^{*} \text {, Blew et al. }(2013 b)^{\psi} \text {, Hill } \\
\text { et al. }(2014)^{\delta} \text {, Hüppop et al. }(2006)^{*} \text {, and van } \\
\text { de Laar }(2007)^{\delta} \text { : gas platform }\end{array}$ & $\begin{array}{l}\text { Kahlert et al. }(2011)^{\delta} \\
\text { (periods of low } \\
\text { visibility very } \\
\text { infrequent) }\end{array}$ \\
\hline & Permanent/intense light & $\begin{array}{l}\text { Blew et al. }(2013 a)^{\psi} \text {, Hüppop et al. (2006)*, and van } \\
\text { de Laar }(2007)^{\delta} \text { : gas platform }\end{array}$ & \\
\hline & Lighting high in red spectrum & van de Laar $(2007)^{\delta}$ : gas platform & $\begin{array}{l}\text { Petersen et al. }(2006)^{\delta} \text { : } \\
\text { flashing red light }\end{array}$ \\
\hline & $\begin{array}{l}\text { Trapping effect causing } \\
\text { disorientation, increase in } \\
\text { energy consumption and } \\
\text { collision risk }\end{array}$ & $\begin{array}{l}\text { Aumüller et al. (2011)*, Blew et al. }(2013 b)^{\psi} \text {, } \\
\text { Hüppop et al. (2006)*, and van de Laar }(2007)^{\delta} \text { : gas } \\
\text { platform }\end{array}$ & \\
\hline
\end{tabular}


Table 4 continued

\begin{tabular}{|c|c|c|c|}
\hline \multicolumn{2}{|l|}{ Hypotheses } & Plausible/supported & $\begin{array}{l}\text { Implausible/ } \\
\text { not-supported }\end{array}$ \\
\hline \multicolumn{4}{|c|}{ Decrease of potential collision risk } \\
\hline \multirow[t]{5}{*}{$\begin{array}{l}\text { Avoidance } \\
\text { behavior }\end{array}$} & Species-specific & $\begin{array}{l}\text { Furness et al. (2013)*, Mateos et al. }(2011)^{\psi} \text {, Petersen et al. }(2006)^{\delta} \text {, and } \\
\text { Plonczkier and Simms }(2012)^{*}\end{array}$ & \\
\hline & Weather dependent & $\begin{array}{l}\text { Aumüller et al. (2011)*, Coppack et al. }(2011)^{\psi} \text {, Hüppop et al. (2006)*, and } \\
\text { Reichenbach and Grünkorn }(2011)^{\psi}\end{array}$ & $\begin{array}{l}\text { Pettersson } \\
(2005)^{\delta}\end{array}$ \\
\hline & $\begin{array}{l}\text { Horizontal/vertical/between } \\
\text { turbines }\end{array}$ & $\begin{array}{l}\text { Desholm and Kahlert }(2005)^{*} \text {, Kahlert et al. }(2011)^{\delta} \text {, and Plonczkier and } \\
\text { Simms }(2012)^{*}\end{array}$ & \\
\hline & Macro-/micro-avoidance & $\begin{array}{l}\text { Christensen et al. }(2004)^{\delta} \text {, Desholm and Kahlert (2005)*, Furness et al. (2013)*, } \\
\text { Hill et al. }(2014)^{\delta} \text {, Petersen et al. }(2006)^{\delta} \text {, and Pettersson and Fågelvind } \\
(2011)^{\delta}\end{array}$ & \\
\hline & $\begin{array}{l}\text { Increased micro-avoidance at } \\
\text { operating wind turbines }\end{array}$ & Hill et al. $(2014)^{\delta}$ & \\
\hline Habituation & Over the years & Plonczkier and Simms (2012)* & \\
\hline
\end{tabular}

Different publication types are indicated: peer-reviewed article $(*)$, peer-reviewed synthesis $\left({ }^{\mathfrak{h}}\right)$, study/report $\left({ }^{\delta}\right)$, and conference contribution $\left({ }^{\psi}\right)$

time might increase collision risk. Rydell et al. (2012) concluded that consistent mortality rates likely indicate that birds do not adapt to collision risk over the years. Besides actual collision with wind turbines, there are also indirect impacts that can lead to additional raptor mortality such as reproductive skipping as a result of adult mortality (Bevanger et al. 2010, Martínez-Abraín et al. 2012). The possible effect on the population of reduced breeding attempts and success should not be underestimated (Bellebaum et al. 2013). In some cases, like in Castellón, Spain (Martínez-Abraín et al. 2012), or La Venta II in Mexico (Ledec et al. 2011), authors assumed that the additional mortality from wind farms might lead to a population decline. With further wind energy development, Bellebaum et al. (2013) stated that a decline is also likely for the populations of red kites (Milvus milvus) in Brandenburg, Germany.

\section{Main Effects on Wildlife Offshore}

\section{Migratory Birds}

Stienen et al. (2007) stated that even small declines in adult survival of migratory seabirds can have an effect on the species population. The effects offshore wind energy development might have on birds include (1) habitat loss or change due to the siting of a wind farm, (2) disturbance due to, e.g., noise, reflexes, and shadows, (3) barrier effects resulting in an increase of energy consumption, and (4) collision (Hüppop et al. 2006). For migratory birds, collision with offshore turbines is most likely of main concern. Observations of collision events at offshore wind farms are very rare (e.g., Pettersson 2005) but have been reported from other offshore structures such as oil and gas platforms (Hüppop et al. 2006). At the research platform FINO I, German EEZ (Exclusive Economic Zone), Aumüller et al. (2011) reported 88 bird fatalities in one night. Hüppop et al. (2006) reported 443 birds of 21 species from Oct 2003 to Dec 2004 at the same platform. However, it remains uncertain whether this data can be transferred to offshore wind farms, due to differences in structure and lighting (Hill et al. 2014; Hüppop et al. 2006).

Even with today's rapid enhancement of surveillance technologies (Hill et al. 2014), the quantification of fatality rates at offshore wind farms remains challenging. An unknown number of colliding birds may fall directly into the sea, are drifted off the platform by wind, or removed by scavengers (Aumüller et al. 2011; Hüppop et al. 2006). In order to assess effects offshore, it is important to understand the factors that influence migration activity as well as avoidance responses (cf. Table 4).

\section{Seasonal and Spatial Patterns of Bird Migration}

Wind farms are constructed in areas with high wind yield, areas which also happen to be important corridors for migratory birds. The North and Baltic Sea, where several hundred million birds cross twice every year (Hüppop et al. 2006; Stienen et al. 2007), the Strait of Gibraltar, representing a major migration route for Palaeo-African soaring migrants (Muños Gallego et al. 2011), and flight paths along the Atlantic Outer Continental Shelf in the U.S. (Burger et al. 2011, 2012) are examples of important offshore migration corridors. Bird migration takes place during the entire year, with peaks during spring and autumn (Hill et al. 2014; Hüppop et al. 2006). However, mass 
migration events take place on only few occasions (Aumüller et al. 2011; Hill et al. 2014; Hüppop et al. 2006). When flying across water, migration intensity increases near coasts as most birds use coast lines as corridors (Hüppop et al. 2004, 2006). The collision risk seemingly increases with bird abundance (Hüppop et al. 2006, 2012) and with reverse migration due to repeated fly-bys (Hüppop et al. 2006). Furthermore, bird migration appears not only to be seasonal but species-specific, and is also subject to inter-annual variation (Hüppop et al. 2012; Pettersson and Fågelvind 2011). This effect is likely to matter even stronger offshore than on land (Aumüller et al. 2013). Burger et al. (2012) reported that different local populations of the same species (Calidris canutus) showed widely variable migration routes. Hüppop and Winkel (2006) stated that spring migration of the long-distant migrant European pied flycatcher (Ficedula hypoleuca) correlated with temperature regimes along the migration route. Migration intensity also seems to be dependent on wind direction differing between seasons, as a clear increase in migration activity could be observed in conditions with tailwinds. However, during strong tailwinds, there was a reverse effect (Hüppop and Winkel 2006).

\section{Times of High Flight Activity}

A majority of migrating birds show nocturnal flight behavior when flying toward and back from their wintering and breeding grounds (Christensen et al. 2004; Hill et al. 2014; Hüppop et al. 2012). During a study carried out at FINO I, German EEZ from 2004 to 2007, it was observed that ca. $80 \%$ flew during nights, increasing from the beginning of the night and peaking before sunrise, whereas the lowest number of recordings occurred during late afternoon (Hüppop et al. 2012). By recording bird calls, Hill et al. (2014) confirmed high rates predominantly after midnight, especially during spring and autumn migration. The acoustic activity underlies variability not only between daytime, but also between years and nights. However, Plonczkier and Simms (2012) found that only $15 \%$ of the autumn migration of pink-footed geese (Anser brachyrhynchus) appeared at night (7:00 pm-7:00 am), whereas most geese passed the study area in early afternoon (12:00 am-2:00 pm).

\section{Flight Altitude and Alteration}

Collision risk is strongly linked to flight altitude during migration, which varies between species (e.g., Blew et al. 2013b; Furness et al. 2013), weather conditions (e.g., Aumüller et al. 2011; Reichenbach and Grünkorn 2011), seasons (Hüppop et al. 2004; Pettersson and Fågelvind 2011), and daytime (Hüppop et al. 2004). It can be expected that birds fly at heights where energy consumption is low, dependent on the length of the flight, experience of the birds, wind speed and direction, as well as visibility due to weather conditions (Hüppop et al. 2006). Many authors reported that during favorable weather conditions, the majority of migration appears above the rotor swept zone (e.g., Aumüller et al. 2011; Coppack et al. 2011; Reichenbach and Grünkorn 2011). Pettersson and Fågelvind (2011) stated only $17 \%$ of the songbirds flew lower than $150 \mathrm{~m}$ ( $8 \%$ in spring), thus at risk of collision. Hüppop et al. (2004) identified flight altitudes below $200 \mathrm{~m}$ for more than $30 \%$ of all migratory birds at Helgoland and the Island of Ruegen, as well as $20 \%$ around at the Island of Fehmarn. Birds flying directly above the water surface and therefore below the rotor were excluded, since they were not detected by the radar. It was also observed that spring migration took place at lower altitudes (Hüppop et al. 2004). Nevertheless, Hüppop et al. (2006) stated about half of the birds are likely to fly at altitudes that would bring them within reach of the rotor. A several-year study from Hill et al. (2014) using vertically rotating marine radar even suggests that the highest flight activity appears below 200 m over all seasons.

\section{Species-Specific Avoidance Behavior}

Avoidance behavior can be categorized into (1) macroavoidance, a modification of the flight path avoiding the wind farm, and (2) micro-avoidance of turbines within a wind farm (Cook et al. 2012; Desholm and Kahlert 2005). Birds showed avoidance by altering their flight horizontally (Christensen et al. 2004) and vertically (Plonczkier and Simms 2012) and by using the interspace between the turbines (Christensen et al. 2004; Desholm and Kahlert 2005). A study from Plonczkier and Simms (2012) revealed no avoidance behavior during construction but increasing with the years during operation, most likely indicating habituation.

However, overall fatality rates of migratory birds offshore seem to be lower than expected, due to speciesspecific avoidance behavior (e.g., Desholm and Kahlert 2005; Kahlert et al. 2011; Petersen et al. 2006; Pettersson 2005; Plonczkier and Simms 2012; Reichenbach and Grünkorn 2011). Pettersson (2005) calculated a collision risk factor for the total number of migratory waterfowl passing through two Swedish offshore wind farms during spring and autumn migration. He assessed at Utgrunden, approximately $0.2 \%$ of the flocks migrating in spring and $0.3 \%$ of the flocks passing Yttre Stengrund in autumn are at risk of collision, resulting in an estimated fatality rate of one bird per turbine and year. At the two Danish offshore wind farms Nysted and Horns Rev, $78 \%$ and 71-86 \% of the approaching bird flocks avoided entering the wind 
farm. Avoidance responds appeared at greater distance during day than during night (Petersen et al. 2006).

Passerines are likely to be more vulnerable, flying relatively low and in large numbers (e.g., Aumüller et al. 2011; Hüppop et al. 2004, 2006). Also, large birds, due to reduced maneuverability as a result of morphology (Furness et al. 2013; Garthe and Hüppop 2004), and fast-flying nocturnal birds such as ducks (Grünkorn 2013), have been classified as vulnerable. Kahlert et al. (2011) stated that at the offshore wind farm Rødsand 2 located close to the Hyllekrog Peninsula, Denmark, red kites (Milvus milvus) were the only species of concern. In conditions with low visibility, red kites spend more time within the wind farm soaring, for which a collision rate of 7-13 birds had been estimated.

The adjustment of flight paths to avoid wind farms might lead to an increase in energetic costs (barrier effects). Masden et al. (2009) observed the flight behavior of common eiders (Somateria molissima), a long-distance migratory seaduck, by using surveillance radar at the Danish offshore wind farm Nysted. They concluded that the additional distance of $500 \mathrm{~m}$ traveled by the birds in relation to the $1.400 \mathrm{~km}$ migration distance would not result in a significant effect in terms of energy consumption (Masden et al. 2009). Pettersson (2005) also observed a marginal increase in energy cost for migratory waterfowl due to the adjustment of flight paths at two Swedish wind farms. Migratory species, mainly eiders, but also cormorants (Phalacrocorax carbo), ducks, and geese avoided the wind farms by flying at a distance of at least $1 \mathrm{~km}$ from the turbines. They altered their flight paths $1-2 \mathrm{~km}$ before the wind farm area, which led to an increase of $0.2-0.5 \%$ of the total migration distance (total of 1.2-2.4 km) (Pettersson 2005). However, with further wind energy development and other anthropogenic activities, an effect on population level cannot be excluded. Additionally, the effect might be significantly increased for species passing through wind farm areas on a daily basis (Masden et al. 2009).

Hill et al. (2014) investigated bird distribution at the German offshore wind farm alpha ventus during nights and found that migration intensity can be considerably higher inside than outside the wind farm. However, bird distribution can vary among nights. This was most likely not only influenced by wind condition and visibility but also by the operational status of the wind turbines. During the same night, when 88 bird fatalities were reported by Aumüller et al. (2011) at the research platform FINO I located in the close vicinity of alpha ventus, no birds were recorded within the rotor swept zone of the wind turbine AV 4 (Hill et al. 2014). Nevertheless, migration intensity was even higher inside than outside the wind farm. Hill et al. (2014) hypothesized that this possibly indicated micro-avoidance of the turbine connected to the blade movement. However, since only one turbine was investigated, collision events at residual turbines could not be ruled out due to turbinespecific collision risk (Hill et al. 2014).

\section{Low Visibility and Adverse Weather Conditions}

Avoidance behavior is likely very high during daytime (Petersen et al. 2006) and with favorable weather conditions (Reichenbach and Grünkorn 2011). Christensen et al. (2004) stated that avoidance was more accurate during day than night time. At night, more flocks entered a wind farm but kept a higher distance to the single turbines (Desholm and Kahlert 2005). Other studies revealed an even higher avoidance rate during nights due to a flight altitude well above the rotor swept zone (Reichenbach and Grünkorn 2011). Higher flight altitudes during night were also reported by Hill et al. (2014) and also for songbirds by Pettersson and Fågelvind (2011). Songbirds flew even higher during foggy nights, causing them to fly above the cloud cover (Pettersson and Fågelvind 2011).

Many authors stated that adverse weather conditions can lead to a decrease in flight altitude of migrating birds, causing them to enter the rotor swept zone (e.g., Aumüller et al. 2011; Coppack et al. 2011; Hüppop et al. 2006). Essentially, adverse weather conditions in the departure area can lead to a complete suppression of migratory activity (Richardson 2000 in Hein et al. 2011a). Studies reveal interrelations between migration activity and cloud cover (Aschwanden et al. 2011: onshore; Nilsson et al. 2006: partial migrants), wind (Aumüller et al. 2011; Hüppop et al. 2004, 2006; van de Laar 2007), temperature (Hüppop and Winkel 2006), atmospheric pressure and pressure changes (Hein et al. 2011a: tested indoors; Shamoun-Baranes et al. 2006) as well as precipitation (Nilsson et al. 2006: partial migrants). Therefore, favorable weather in terms of migration activity includes tailwind and good visibility, whereas strong head wind with low visibility due to precipitation or sea fog most likely accounts for unfavorable migration conditions (Coppack et al. 2011; Hüppop et al. 2006; Plonczkier and Simms 2012).

\section{Attraction to Artificial Light Sources}

Birds that migrate nocturnally, e.g., songbirds and waders, seem to be attracted to illuminated obstacles, as it was observed for offshore gas production and research platforms, lighthouses, and offshore wind turbines (Aumüller et al. 2011; Hill et al. 2014; van de Laar 2007). This response appears to be particularly high when visibility is low (e.g., fog, drizzle). Birds were observed circling the light source repeatedly, showing signs of disorientation and also using the structure as a potential resting ground. As a result, the 
increase in energy consumption does not only lead to a possible increase in collision risk (Aumüller et al. 2011), but can likely cause mortality due to exhaustion or starvation (Blew et al. 2013b; Hüppop et al. 2006; van de Laar 2007). Large-scale continuous lighting is likely to attract a large number of birds (Blew et al. 2013a; van de Laar 2007). The influence that light color might have on this effect still needs to be understood (Blew et al. 2013a). However, van de Laar (2007) stated that using partial lighting low in red spectrum most likely reduces attraction. Findings of Petersen et al. (2006) could not confirm the attraction hypothesis for large nocturnal migrating waterbirds. Observing flight behavior of passerines at night at the offshore wind farm Rødsand 2, Kahlert et al. (2011) could not confirm any attraction responses as well. However, during the duration of the study, nights with adverse weather conditions were very scarce.

\section{Marine Mammals}

Gordon et al. (2007) characterized species with high acoustic sensitivity, like seals (i.e., Halichoerus grypus, Phoca vitulina) and cetaceans, as most likely to be affected by offshore wind energy development, but especially inshore species such as the harbor porpoise (Phocoena phocoena) and the bottlenose dolphin (Tursiops truncatus). Once offshore development will be ongoing in deeper waters, further species might be affected (Gordon et al. 2007). The acoustic vulnerability against offshore wind farm pile driving varies between different species and acoustic groups (Lucke et al. 2009). Dähne et al. (2014b) stated that acoustic vulnerability can also vary between individuals depending on age and sex. Up to today, the majority of surveys focus on potential effects and their mitigation on harbor porpoises (Dähne et al. 2014a). Assessing the effects of wind farm development on marine mammals remains a challenge, especially due to inter-annual population dynamics, seasonal patterns, high animal mobility, and site characteristics (Gordon 2012; Scheidat et al. 2011).

\section{Habitat Change}

Offshore wind farms are often located at submerged sandbanks, which account as important habitats for marine mammals, especially during nursing and calving (Koschinski 2002 in Carstensen et al. 2006). Negative as well as positive effects might result from the turbine structures and the change in anthropogenic activities within the wind farm site (Lindeboom 2012; Thompson et al. 2013). The exclusion of fishery, including bottom trawling, might cause an increase of prey availability and a decrease in by-catch of marine mammals. The introduction of hard substrate might lead to higher structural heterogeneity around the turbine foundations and the scour protection serving as artificial reefs, with an increasing habitat quality for prey too (Gordon 2012; Lindeboom 2012; Scheidat et al. 2011; Thompson et al. 2013; Winter et al. 2012). Offshore wind farms might even serve as marine protected areas (Bergström et al. 2013a; Lindeboom 2012). The significance of these areas in the immediate vicinity of the foundations remains debatable, as they account for only $1 \%$ of a wind farm in total (Bergström et al. 2013b; van Hal and Griffioen 2012). However, a recent study by Russell et al. (2014) has observed seals entering two different wind farms in Germany (alpha ventus) and England (Sheringham Shoal), concentrating around the turbine structures and showing reduced horizontal speed, indicating foraging behavior. However, this was observed only four and 2 years after construction, respectively. With further establishment of artificial reefs over time, more individuals might use the areas as foraging grounds (Russell et al. 2014).

Furthermore, effects from re-suspension of potentially polluted sediment together with turbidity during construction and cabling cannot be ignored, but are only shortlived. The risk of contamination from leaks or spills increases due to higher risk of ship collision within the wind farms, along with the use of hydraulic fluids from operational devices. This could affect the health and breeding success of species, and also indirectly due to an accumulation within the food web (Simms and Ross 2000). Additionally, increased ship traffic during construction, maintenance, and decommissioning could lead to an increase in collision with ships as well as in disturbance (Laist et al. 2001 in SMRU 2009). A change in electromagnetic fields due to cabling influencing animal navigation, entanglement in cables, and entrapment in facility structures cannot be excluded, and remain subjects for further research (SMRU 2009). Nevertheless, Russell et al. (2014) observed seals navigating between turbine structures without incident.

\section{Noise Emission During Operation}

Underwater noise emission has been the focus of most studies on marine mammals in the context of offshore wind energy development. The majority of those indicate that the impact of underwater operational noise has negligible or no negative effect on marine mammals (Gordon et al. 2007; Madsen et al. 2006; Teilmann et al. 2012; Tougaard et al. 2006a; Tougaard 2013). Negative effects from auditory masking, which describes the restrained communication of individuals due to other sound sources, are unlikely to be significant due to the low spectral overlap with echolocation signals of harbor porpoises (Gordon 2012; Tougaard et al. 2009a). Koschinski et al. (2003) 
added that the masking effect is more likely to affect harbor seals (Phoca vitulina). Notwithstanding, the transmission of noise from operating wind turbines depends not only on the foundation type (Ødegaard and DaneskioldSamsøe A/S 2000 in Simmonds and Brown 2010) and on sound propagation conditions (Madsen et asl. 2006), but also on the occurring wind speed (Lucke et al. 2008). Lucke et al. (2008) added further that masking is possible from even smaller turbines, but only at very short distances and during times of strong winds.

Other studies revealed that a behavioral reaction to operational noise emission in the immediate surroundings cannot be completely eliminated (Koschinski et al. 2003; Tougaard et al. 2009a) and is also dependent on the lowfrequency hearing ability of the species. With growing offshore wind energy development, noise emission from operation is more likely to be significant and also dependent on the presence of other noise sources, e.g., shipping (Madsen et al. 2006), making the assessment of cumulative effects crucial.

\section{Noise Emission During Construction}

Different construction techniques (e.g., piling, dredging, and drilling) are used depending on the type of foundation. The strongest effect on marine mammals is most likely caused by the site-specific noise emission from the percussive piling during construction (e.g., Bailey et al. 2010; Danish Energy Agency 2013; Gerdes and Ludwig 2014; Gordon et al. 2007; Gordon 2012) and depends on factors influencing sound propagation including salinity, water depth, and temperature. These conditions are subject to daily variations, influenced by weather patterns (Gerdes and Ludwig 2014). It was found that the emission of $205 \mathrm{~dB}$ re $1 \mu \mathrm{Pa}$ peak to peak sound pressure level (SPL) at $100 \mathrm{~m}$ distance, detectable up to $80 \mathrm{~km}$, was generated during pile driving activity from two $5 \mathrm{MW}$ turbines at $>40 \mathrm{~m}$ water depth (Bailey et al. 2010). Nedwell et al. (2007) found a source level of even $243-257 \mathrm{~dB}$ re $1 \mu \mathrm{Pa}$ at $1 \mathrm{~m}$ distance within five different piling operations, with an average value of $250 \mathrm{~dB}$ re $1 \mu \mathrm{Pa}$ at $1 \mathrm{~m}$.

Bailey et al. (2010) showed that a population of bottlenose dolphins (Tursiops truncatus) would be at risk of auditory injury within a $100 \mathrm{~m}$ distance to a piling site. Changes in behavior were likely to occur up to a distance of $50 \mathrm{~km}$ (Bailey et al. 2010). Ketten and Finneren (2004 in Lucke et al. 2009) predefined the Temporary Threshold Shift (TTS) for bottlenose dolphins and beluga whales (Delphinapterus leucas), representing mid-frequency cetaceans, of $224 \mathrm{~dB}$ re $1 \mu \mathrm{Pa}$ peak to peak SPL (195 dB re $1 \mu \mathrm{Pa}^{2}$ s sound exposure level (SEL)) using pulsed sounds. Lucke et al. (2009) designated the TTS limit of $200 \mathrm{~dB}$ re 1 peak to peak SPL at $1 \mathrm{~m}\left(164 \mathrm{~dB}\right.$ re $1 \mu \mathrm{Pa}^{2} \mathrm{~s}$ SEL) for porpoises for a single impulse using an air gun. Nedwell et al. (2007) found that marine mammals would be at risk of auditory injury, when exposed to noise at a sound level of approximately $130 \mathrm{~dB}_{\mathrm{ht}}$ for a few seconds. When exceeding the species- and/or auditory group-specific tolerance of their auditory system even further, Permanent Threshold Shifts (PTS) might occur. However, not only PTS but also TTS can have severe consequences for the affected individual (Lucke et al. 2009), as marine mammals use sounds for communication, navigation, and location of food (Kastelein 2013a). Tougaard et al. (2012) and Dähne et al. (2014b) emphasized that even single incidences where species behavior is interrupted, i.e., to mate, feed, or interact, could have an effect on the population in the long term. However, this effect is virtually impossible to quantify (Dähne et al. 2014b).

The concern of repetitive sound emission of 1-2 strokes per second and simultaneous construction activities at different sites or even within the same wind farm might lead to an accumulation of noise emissions (e.g., Gordon et al. 2009 in Tougaard et al. 2012; Lucke et al. 2009). Matuschek and Betke (2009) emphasized that for the installation of each turbine, in this case tripod or jacket foundation, 15,000 strikes were necessary on average for each at a source level exceeding $230 \mathrm{~dB}$ re $1 \mu \mathrm{Pa}$ at $1 \mathrm{~m}$. They assumed that this effect was most likely significant. Nedwell et al. (2007) stated that the exposure to a relatively low sound level would not result in permanent hearing loss, in this case $90 \mathrm{~dB}$, but could have a negative effect once the exposure persists over a longer duration $(8 \mathrm{~h})$. Lucke et al. (2009) added that with piling intervals being shorter than the species-specific recovery time from TTS, an accumulation of auditory effects is likely to occur. Harbor porpoises in particular show a relatively slow recovery rate (Lucke et al. 2009).

The risk of actual hearing damage would affect only the individuals in the immediate surroundings of the piling site, whereas behavioral reactions occur up to $10 \mathrm{~s} \mathrm{~km}$ from the sound source (Brandt et al. 2009; Tougaard et al. 2009a, 2012). Animal response to underwater noise is highly variable due to propagation conditions (Gordon et al. 2007; Gordon 2012). The produced sound immission is not solely emitted into the water body, but also into the ground and released into the water body at 20$50 \mathrm{~m}$ distance to a monopole, depending on the sediment (Lippert et al. 2014). Lastly, additional noise emission from rock dumping for scour protection during construction and also from geotechnical surveys, carried out before construction to exploit the suitability of the seabed, needs to be further considered (Nedwell and Howell 2004; SMUR 2009). 
Table 5 Predominant hypotheses on wind energy-induced effects on marine mammals

\begin{tabular}{|c|c|c|}
\hline Hypothesis & Plausible/supported & Implausible/not-supported \\
\hline \multicolumn{3}{|l|}{ Habitat change } \\
\hline $\begin{array}{l}\text { Increase in prey availability due to } \\
\text { exclusion of fishery }\end{array}$ & $\begin{array}{l}\text { Scheidat et al. }(2011)^{*}, \text { SMRU }(2009)^{\omega} \text {, and } \\
\text { Simmonds and Dolman }(2008)^{\psi}\end{array}$ & \\
\hline $\begin{array}{l}\text { Increase in habitat quality due to } \\
\text { artificial reef-effect }\end{array}$ & $\begin{array}{l}\text { Gill }(2005)^{\mathrm{f}} \text {, Russell et al. (2014)*, Scheidat et al. } \\
(2011)^{*} \text {, SMRU }(2009)^{\omega} \text {, and Simmonds and } \\
\text { Dolman }(2008)^{\psi}\end{array}$ & \\
\hline $\begin{array}{l}\text { Entanglement/entrapment in } \\
\text { cables/structures }\end{array}$ & Simmonds and Brown $(2010)^{\mathrm{f}}$ & \\
\hline $\begin{array}{l}\text { Collision with floating or } \\
\text { submerged structures }\end{array}$ & Gill $(2005)^{\mathrm{f}}$ and Simmonds and Brown $(2010)^{\mathrm{f}}$ & Russell et al. (2014)* \\
\hline $\begin{array}{l}\text { Disorientation due to change of } \\
\text { magnetic fields }\end{array}$ & $\begin{array}{l}\text { Gill }(2005)^{\mathrm{f}}, \text { SMRU }(2009)^{\omega} \text {, Simmonds and } \\
\text { Dolman }(2008)^{\psi}\end{array}$ & Lucke et al. $(2008)^{\delta}$ \\
\hline $\begin{array}{l}\text { Increased vessel activity causing } \\
\text { stress/disturbance and risk of } \\
\text { strikes }\end{array}$ & $\begin{array}{l}\text { Gordon }(2012)^{\psi} \text {, Nedwell and Howell }(2004)^{\omega} \text {, } \\
\text { SMRU }(2009)^{\omega} \text {, and Simmonds and Dolman } \\
(2008)^{\psi}\end{array}$ & $\begin{array}{l}\text { Refuge function: Lindeboom }(2012)^{\psi} \text {, } \\
\text { and Scheidat et al. }(2011)^{*}\end{array}$ \\
\hline $\begin{array}{l}\text { Contamination due to leaks, spills, } \\
\text { and biocides }\end{array}$ & $\begin{array}{l}\text { SMRU }(2009)^{\omega} \text {, Simmonds and Brown }(2010)^{\mathrm{f}} \text {, and } \\
\text { Simms and Ross }(2000)^{\mathrm{h}}\end{array}$ & \\
\hline \multicolumn{3}{|l|}{ Pre-construction } \\
\hline $\begin{array}{l}\text { Increased vessel activity causing } \\
\text { stress/disturbance and risk of } \\
\text { strikes }\end{array}$ & $\begin{array}{l}\text { Gordon }(2012)^{\psi}, \text { Nedwell and Howell }(2004)^{\omega} \text {, and } \\
\text { Simmonds and Dolman }(2008)^{\psi}\end{array}$ & \\
\hline $\begin{array}{l}\text { Noise emission from wind farm- } \\
\text { related geophysical surveys }\end{array}$ & $\begin{array}{l}\text { Gordon }(2012)^{\psi} \text {, Nedwell and Howell }(2004)^{\omega} \text {, } \\
\text { SMRU (2009) }\end{array}$ & \\
\hline \multicolumn{3}{|l|}{ During construction } \\
\hline $\begin{array}{l}\text { Displacement due to noise } \\
\text { emission during piling }\end{array}$ & $\begin{array}{l}\text { Brandt et al. }\left(2009^{\delta}, 2011^{*}\right) \text {, Carstensen et al. } \\
(2006)^{*}, \text { Dähne et al. }(2013)^{*}, \text { Haelters et al. } \\
(2012)^{\delta} \text {, Kastelein et al. }(2013 \mathrm{~b})^{*}, \text { Nedwell and } \\
\text { Howell }(2004)^{\omega} \text {, Nedwell et al. }(2007)^{\delta} \text {, Nehls and } \\
\text { Betke }(2011)^{\delta} \text {, Tougaard et al. }\left(2006 a^{\delta}, b^{\delta} \text {, }\right. \\
\text { 2009a*), and Wahl et al. }(2013)^{\psi}\end{array}$ & \\
\hline $\begin{array}{l}\text { Behavioral disturbance due to } \\
\text { underwater noise (e.g., feeding, } \\
\text { nursing, resting, migration) }\end{array}$ & $\begin{array}{l}\text { Dähne et al. }(2014 b)^{\psi} \text {, Gordon }(2012)^{\psi} \text {, Kastelein } \\
(2013 \mathrm{a})^{\psi} \text {, SMRU }(2009)^{\delta} \text {, and Tougaard et al. } \\
\left(2009 a^{*}, 2012^{\psi}\right)\end{array}$ & \\
\hline Temporal hearing impairment & $\begin{array}{l}\text { Gordon }(2012)^{\psi} \text {, Kastelein }(2013 a)^{\psi} \text {, Lucke et al. } \\
(2009)^{*} \text {, and Nedwell et al. }(2007)^{\delta}\end{array}$ & \\
\hline $\begin{array}{l}\text { Hearing loss/injury/death close to } \\
\text { piling site }\end{array}$ & $\begin{array}{l}\text { Gordon }(2012)^{\psi} \text {; Kastelein }(2013 a)^{\psi} \text {; Lucke et al. } \\
(2009)^{*} \text {; Nedwell and Howell }(2004)^{\omega} \text {; Nedwell } \\
\text { et al. }(2007)^{\delta}\end{array}$ & \\
\hline $\begin{array}{l}\text { Increased risk due to } \\
\text { simultaneous, long-lasting } \\
\text { piling activity or contemporary } \\
\text { piling intervals }\end{array}$ & $\begin{array}{l}\text { Dähne et al. (2013)*, Lucke et al. (2009)*, Madsen } \\
\text { et al. }(2006)^{\mathrm{f}} \text {, Nedwell et al. }(2007)^{\delta} \text {, Nehls and } \\
\text { Betke }(2011)^{\delta} \text {, and Thompson et al. }(2010)^{*}\end{array}$ & \\
\hline $\begin{array}{l}\text { Mother-calf-separation/ } \\
\text { disturbance }\end{array}$ & Dähne et al. (2014b) $)^{\psi}$, and Kastelein $(2013 a)^{\psi}$ & \\
\hline $\begin{array}{l}\text { Increased vessel activity causing } \\
\text { stress/disturbance and risk of } \\
\text { strikes }\end{array}$ & $\begin{array}{l}\text { Carstensen et al. }(2006)^{*} \text {, Gordon }(2012)^{\psi} \text {, Nedwell } \\
\text { and Howell }(2004)^{\omega} \text {, SMRU }(2009)^{\omega} \text {, Simmonds } \\
\text { and Dolman }(2008)^{\psi} \text {, and Simmonds and Brown } \\
(2010)^{\mathrm{f}}\end{array}$ & \\
\hline Tendency to return after piling & $\begin{array}{l}\text { Brandt et al. }(2009)^{\delta} \text {, Haelters and Vanermen } \\
(2013)^{\psi} \text {, Nehls and Betke }(2011)^{\delta} \text {, Scheidat et al. } \\
(2011)^{*} \text {, Tougaard et al. }(2006 \mathrm{~b})^{\delta}: \text { Horns Rev, and } \\
\text { Wahl et al. }(2013)^{\psi}\end{array}$ & Tougaard et al. $(2006 \mathrm{a})^{\delta}: 2$ years \\
\hline $\begin{array}{l}\text { Disperse of sediment causing re- } \\
\text { suspension of potentially } \\
\text { polluted sediment and turbidity }\end{array}$ & $\begin{array}{l}\text { Carstensen et al. }(2006)^{*} \text {, Gill }(2005)^{\mathrm{f}} \text {, and } \\
\text { Simmonds and Dolman }(2008)^{\psi}\end{array}$ & \\
\hline
\end{tabular}


Table 5 continued

\begin{tabular}{|c|c|c|}
\hline Hypothesis & Plausible/supported & Implausible/not-supported \\
\hline \multicolumn{3}{|l|}{ During operation } \\
\hline $\begin{array}{l}\text { Masking causing disruption of } \\
\text { usual behavior }\end{array}$ & $\begin{array}{l}\text { Koschinski et al. (2003)*: harbor seals; Lucke } \\
(2008)^{\delta} \text { : at very short distance }\end{array}$ & $\begin{array}{l}\text { Gordon }(2012)^{\psi} \text {, Haelters and Vanermen }(2013)^{\psi} \text {, } \\
\text { Koshinski et al. }(2003)^{*} \text { : harbor porpoises, Lucke } \\
(2008)^{\delta} \text {, Nehls and Betke }(2011)^{\delta} \text {, and Tougaard } \\
\text { et al. }(2009 \mathrm{~b})^{*}\end{array}$ \\
\hline $\begin{array}{l}\text { Avoidance of wind farm area/ } \\
\text { change of behavior due to } \\
\text { noise emission and vibration }\end{array}$ & $\begin{array}{l}\text { Simmonds and Dolman }(2008)^{\psi} \text { and Tougaard et al. } \\
(2009 \text { b)*: porpoises at very short distance/seals } \\
\text { likely }\end{array}$ & $\begin{array}{l}\text { Dähne et al. (2014a) }{ }^{\delta}, \text { McConnell et al. }(2012)^{\delta} \text {, } \\
\text { Nedwell et al. }(2007)^{\delta} \text {, and Scheidat et al. }(2011)^{*}\end{array}$ \\
\hline \multicolumn{3}{|l|}{ During decommissioning } \\
\hline $\begin{array}{l}\text { Habitat loss due to removal of } \\
\text { structure }\end{array}$ & Gill $(2005)^{\mathrm{f}}$, and Gordon $(2012)^{\psi}$ & \\
\hline $\begin{array}{l}\text { Injury or behavioral response due } \\
\text { to noise emission (e.g., } \\
\text { explosion, cutting) }\end{array}$ & $\begin{array}{l}\text { Gordon et al. }(2007)^{\delta} \text {, Lucke et al. }(2009)^{*} \text {, Prior } \\
\text { and McMath }(2008)^{\psi} \text {, SMRU }(2009)^{\delta} \text {, and } \\
\text { Simmonds and Dolman }(2008)^{\psi}\end{array}$ & \\
\hline $\begin{array}{l}\text { Increased vessel activity causing } \\
\text { stress/disturbance and risk of } \\
\text { strikes }\end{array}$ & $\begin{array}{l}\text { Nedwell and Howell }(2004)^{\omega} \text {, and Simmonds and } \\
\text { Brown }(2010)^{\mathrm{f}}\end{array}$ & \\
\hline $\begin{array}{l}\text { Disperse of sediment causing re- } \\
\text { suspension of potentially } \\
\text { polluted sediment and turbidity }\end{array}$ & $\begin{array}{l}\text { Carstensen et al. (2006)*, Gill }(2005)^{\mathrm{f}} \text {, and } \\
\text { Simmonds and Dolman }(2008)^{\psi}\end{array}$ & \\
\hline
\end{tabular}

Different publication types are indicated: peer-reviewed article $(*)$, peer-reviewed synthesis $\left({ }^{\mathfrak{h}}\right)$, synthesis $\left({ }^{(\omega)}\right)$, study/report $\left({ }^{\delta}\right)$, and conference contribution $\left({ }^{\psi}\right)$

\section{Displacement During Construction}

Even though piling leads to significant displacement of porpoises (e.g., Brandt et al. 2011; Dähne et al. 2013; Lucke et al. 2012; Tougaard et al. 2012), there is indication that this effect is most likely short-lived (e.g., BMU 2013; Danish Energy Agency 2013). Displacement might result also from deterrence devices (Dähne et al. 2013), if applied. A study carried out at alpha ventus showed temporal displacement within $20 \mathrm{~km}$ from the piling site, with detection rates increasing with distance from the construction site. The detection rate at 25 and $50 \mathrm{~km}$ distance showed a positive correlation during pile driving, indicating that displaced porpoises moved toward this area (Dähne et al. 2013). The significance of displacement as well as of recovery might be strongly dependent on conditions within the surroundings, such as habitat quality, prey availability, competition, and vessel activity (Scheidat 2012).

The population at Nysted only slowly increased after 2 years subsequent to the piling (Tougaard et al. 2006a). In 2007, about 4 years after the construction phase, there had been no detectable differences of harbor porpoise frequency inside and outside the wind farm (Diederichs et al. 2008). A study from Egmond aan Zee showed a significant post-construction increase in porpoise occurrence, which cannot necessarily be explained by the positive effect of wind farms such as prey availability or the exclusion of fishery. It has been more likely a result of population dynamics and unfavorable conditions within the surrounding area. Furthermore, the returning individuals do not have to belong to the previous population; they might also have recently migrated (Scheidat 2012).

\section{Noise Emission During Decommissioning}

Decommissioning has not yet been significantly studied. However, effects from the removal of the turbine structures using explosives or cutting technologies might become significant (Lucke et al. 2009; SMRU 2009). (cf. Table 5).

\section{Conclusions}

In order to reach global climate protection goals, it is crucial to promote sustainable wind energy development. It is important to recognize that in some cases, like with any other approach to generate electricity, particularly vulnerable species might be affected (Bellebaum et al. 2013; May et al. 2011; Willis et al. 2009). Thus, potential negative effects need to be assessed and effectively mitigated all based on our understanding of the cause and the influencing factors connected herewith. Consolidating the state of knowledge therefore provides the groundwork for the avoidance of negative effects as well as the 
development of adequate mitigation options. During the last decade, extensive research has been carried out showing that there are effects and numerous influencing factors that are already well-understood, while others are still being debated or even remain unknown. Within the last couple of years, research focusing on offshore wind energy has increased substantially, catching up with the vast amount of onshore studies, especially within Europe. Generally, many effects studied seem to underlie a strong site-species-season-specificity, and at least in the case of raptors, even turbine-specificity. This emphasizes the necessity for site-specific baseline studies as well as longterm observations accounting for inter-annual dynamics.

Today, some findings have already evolved into facts many can agree on and are implemented into planning practice. Hence, some species are more vulnerable which can be rooted not only in their low reproduction rate or population size, but also in their morphology, phenology, behavior, and response to turbines. Therefore, the presence of those species, particularly when highly abundant, as well as landscape features that are commonly used as habitat by these species needs to be considered in the siting process. Mountain ridges used by raptors during soaring flights, linear structures used for orientation during migration, areas close to bat maternity colonies or bird breeding sites, as well as areas of high food availability are only some examples stated in the literature. Knowing species behavior and habitat use can guide effective habitat enhancement in the area away from the turbines and at the same time help reduce habitat quality within the risk area, due to, for example, land use management. That way the population of concern can be strengthened in order to compensate for unavoidable effects.

Moreover, vulnerable species might not constantly be susceptible to risk due to a difference in behavior and/or species abundance among seasons or daytimes. This offers the possibility to implement temporary turbine shut downs in order to minimize potential negative effects, for example, during departure of migratory birds or high bat activity in autumn between sunset and sunrise. Also, piling events offshore could take place in times of low porpoise abundance or sensitivity (BMUB 2014). Many potential effects on the analyzed species groups seem to be related to certain weather patterns that can also help predict times when mitigation effort is most needed. Prominent examples are nocturnal migration events offshore during adverse weather conditions or the implementation of algorithms including numerous parameters such as wind speed, temperature, and precipitation to predict times of high bat activity.

Nevertheless, other potential effects are still being debated due to divergent findings, a shortness of field studies, or in part, persisting knowledge gaps. As an example, spatial and temporal migration patterns are in most cases still not fully understood accounting for knowledge that is needed within the scope of smart macro-siting. However, parameters at the departure areas, particularly weather patterns that effect or trigger migration activity, are better understood. This information together with ongoing development of surveillance technologies might help overcome uncertainties and to minimize potential negative effects.

In situations where data of spatial and temporal species distribution can be more thoroughly collected, pre-construction observations might still not correlate with postconstruction conditions. Due to the introduction of the turbine structure, an alteration of species abundance and/or composition might result and thus posing a challenge to impact prediction. We found that some species might be attracted to turbines or their surroundings (i.e., bats and raptors) at least during certain conditions (i.e., nocturnal migratory songbirds), whereas others might be displaced (e.g., breeding bird species). Moreover, species response to the introduction of turbines might change over time indicating possible long-term effects due to, for example, habituation or an increase in food availability as it was suggested for marine mammals (Russell et al. 2014).

Understanding the causes of attraction and displacement sets the ground work for developing effective mitigation measures. For example, turbine lighting seems to have some influence on potential effects which might not always be direct (e.g., migratory birds in adverse weather) but might be indirect (e.g., less attraction of insects). The adaption of turbine lighting could be used to reduce attraction for some species like nocturnal migrants or even increase visibility for others, such as raptors to trigger avoidance behavior. However, only those that are aware of the risk will initiate substantial avoidance behavior. The response to color, type, and intensity of lighting (Blew et al. 2013a; van de Laar 2007) seems to be species group or even species-specific and needs to be further addressed (Blackwell and Fernández-Juricic 2013).

Furthermore, it is important to estimate the level at which an impact is likely to occur, such as the emitted underwater noise level at which Temporary Threshold Shifts (TTS) and Permanent Threshold Shifts (PTS) are likely, or at what distance turbines displacement of, e.g., breeding birds, might appear. Such levels need to be determined under real-life conditions accounting for site- and species-specificity. This makes it challenging to develop thresholds for the permitting procedures and guidelines. In order to come up with significant thresholds, a decent number of studies following the same methodological standards would be required.

It needs to be acknowledged that the research effort has already enhanced environmentally sound wind energy planning. However, future research efforts might focus on 
remaining gaps and uncertainties. The ever crucial question in environmental impact assessments aims at the significance of potential effects, which requires knowledge not only about local population sizes and fatality rates, but also about the threshold up to which additional mortality would be still acceptable (initial take). It must be kept in mind that mortality rates are mostly drawn from estimations. A lot of effort went into the development of estimation approaches considering field survey biases. It remains difficult to quantify potential effects, also accounting for delayed mortality resulting from sub-lethal injury or indirect mortality (e.g., decrease in breeding success, displacement). The magnitude of effects resulting from displacement strongly depends on the remaining habitat in the surrounding of the affected area. In some cases, particularly offshore, the quantification of effects might even remain impossible.

Further development of wind energy will result in an increase in turbine height and rotor diameter, as well as lower turbine cut-in-speed. Other or further species might interact with turbines because of an alteration of species abundance or composition within those heights (e.g., Arnett and Baerwald 2013; Hötker 2006). With wind energy further developing over decades, long-term effects, e.g., habituation, remain unknown in most cases due to a lack of long-time surveys. Assessing such and cumulative effects will become even more crucial, posing another challenge to impact assessment. On the one hand, effects might be intensified, e.g., underwater noise emission during operation, barrier effects for migratory birds, or loss of nesting habitats. At the same time, population trends need to be cross-checked, that is whether any kind of co-evolution of renewable wind energy and biodiversity might be a possible pathway ahead (also by habituation). Even though it is vital to avoid and mitigate impacts on wildlife resulting from wind energy, the magnitude of the impacts might be assessed in relation to other anthropogenic activities and structures as well, in particular to other energy sources (e. g., Erickson et al. 2005).

Conclusively, uncertainties will always remain, especially in terms of cumulative impacts and effects on population level. The implementation of impact prediction models and fatality estimations can help facilitate the planning process, but cannot entirely bridge the gaps. Most importantly, to allow for a sustainable wind energy development, an iterative planning approach elaborating the full scope of macro- to micro-avoidance strategies with substantial baseline studies and disclosing and bundling of monitoring data is required as well as international knowledge exchange and data accessibility. It proves evident that the development of standards for baseline, monitoring, and assessment methods remains a challenge, allowing for a better comparison of research results.
Acknowledgments This article is evolved from the research project "Impacts of wind energy development on wildlife — an international synopsis" carried out by the Environmental Assessment and Planning Research Group of the Berlin Institute of Technology (TU Berlin), funded by the German Federal Ministry for Economic Affairs and Energy (BMWi) on the basis of a decision by the German Bundestag. We would like to thank Victoria D. Gartman for her comments, which helped to improve the manuscript.

\section{References}

Ahlén I (2003) Wind turbines and bats-a pilot study. Uppsala, Sweden. http://publikationer.slu.se/Filer/08WindBatFinalReport. pdf. Accessed 11 June 2013

Ahlén I, Baagøe HJ, Bach L (2009) Behavior of scandinavian bats during migration and foraging at sea. J Mammal. 90(6):13181323. doi:10.1644/09-MAMM-S-223R.1

Amorim F, Rebelo H, Rodrigues L (2012) Factors influencing bat activity and mortality at a wind farm in the mediterranean region. Acta Chiropterolog. 14(2):439-457. doi:10.3161/ 150811012 X661756

Arnett EB (2005) Relationships between Bats and Wind Turbines in Pennsylvania and West Virginia. An Assessment of Fatality Search Protocols, Patterns of Fatality, and Behavioral Interactions with Wind Turbines. A final report submitted to the Bats and Wind Energy Cooperative. Edited by Bat Conservation International. Austin, Texas, USA. http://www.batsandwind.org/ pdf/ar2004.pdf. Accessed 20 June 2013

Arnett EB, Baerwald EF (2013) Impacts of wind energy development on bats: implications for conservation. In: Rick AA and Scott CP (eds.) Bat evolution, ecology, and conservation, Springer New York, p 435-456. doi:10.1007/978-1-4614-7397-8

Arnett EB, Hayes JP, Huso MMP (2006) An evaluation of the use of acoustic monitoring to predict bat fatality at a proposed wind facility in southcentral Pennsylvania. An annual report submitted to the bats and wind energy cooperative. Edited by bat conservation international. Austin, Texas, USA. http://www. batsandwind.org/pdf/precon_pa.pdf. Accessed 25 June 2013

Arnett EB, Huso MMP, Reynolds SD, Schirmacher MR (2007) Patterns of pre-construction bat activity at a proposed wind facility in northwest Massachusetts. An annual report submitted to the bats and wind energy cooperative. Bat Conservation International. Austin, Texas, USA. http://www.batsandwind.org/ pdf/ar2006.pdf. Accessed 21 July 2014

Arnett EB, Brown WK, Erickson WP, Fiedler JK, Hamilton BL, Henry TH et al (2008) Patterns of bat fatalities at wind energy facilities in North America. J Wildl Manag. 72(1):61-78. doi:10. 2193/2007-221

Arnett EB, Hein CD, Patterson R (2011a) Synthesis of activities (2004-2011). Key findings and next steps. Edited by bats and wind energy cooperative. http://www.batsandwind.org/pdf/ BWEC_Synthesis_2004-2011.pdf. Accessed 21 July 2014

Arnett EB, Huso MMP, Schirmacher MR, Hayes JP (2011b) Altering turbine speed reduces bat mortality at wind-energy facilities. Front Ecol Environ 9(4):209-214. doi:10.1890/100103

Arnett EB, Hein CD, Schirmacher MR, Baker M, Huso MMP, Szewczak JM (2011b) Evaluating the effectiveness of an ultrasonic acoustic deterrent for reducing bat fatalities at wind turbines. A final report submitted to the bats and wind energy cooperative. Bat Conservation International. Austin, Texas, USA. http://www.batsandwind.org/pdf/Deterrent\%202009$2010 \% 20$ Field $\% 20$ Study\%20Final\%20Report.pdf. Accessed 21 July 2014 
Aschwanden J, Martin V, Bächler E, Steuri T, Liechti F (2011) Which radar systems are suitable to study what kind of question?-An overview. In: May R, Bevanger K (eds.) Proceedings of the Conference on Wind energy and Wildlife impacts. NINA Report 693. Conference on Wind energy and Wildlife impacts, 2-5 May 2011. Norwegian Institute for Nature Research. Trondheim, Norway, p 11

Aumüller R, Boos K, Freienstein S, Hill K, Hill R (2011) Beschreibung eines Vogelschlagereignisses und seiner Ursachen an einer Forschungsplattform in der Deutschen Bucht. Vogelwarte 49:9-16

Aumüller R, Boos K, Freienstein S, Hill K, Hill R (2013) Weichen Zugvögel Windenergieanlagen auf See aus? Eine Methode zur Untersuchung und Analyse von Reaktionen tagsüber ziehender Vogelarten auf Offshore-Windparks. Vogelwarte 51:3-13

Baerwald EF, Barclay R (2009) Geographic variation in activity and fatality of migratory bats at wind energy facilities. J Mammal 90 (6):1341-1349

Baerwald EF, Barclay RMR (2011) Patterns of activity and fatality of migratory bats at a wind energy facility in Alberta, Canada. J Wildl Manag 75(5):1103-1114. doi:10.1002/jwmg.147

Baerwald EF, D'Amours GH, Klug BJ, Barclay R (2008) Barotrauma is a significant cause of bat fatalities at wind turbines. Curr Biol 18(16):R695-696

Baerwald EF, Edworthy J, Holder M, Barclay R (2009) A large-scale mitigation experiment to reduce bat fatalities at wind energy facilities. J Wildl Manag 73(7):1077-1081. doi:10.2193/2008233

Bailey H, Senior B, Simmons D, Rusin J, Picken G, Thompson PM (2010) Assessing underwater noise levels during pile-driving at an offshore windfarm and its potential effects on marine mammals. Mar Pollut Bull 60(6):888-897. doi:10.1016/j.marpol bul.2010.01.003

Baisner AJ, Andersen JL, Findsen A, Yde Granath SW, Madsen KØ, Desholm M (2010) Minimizing collision risk between migrating raptors and marine wind farms: development of a spatial planning tool. Environ Manag 46(5):801-808. doi:10.1007/ s00267-010-9541-z

Barclay R, Baerwald EF, Gruver JC (2007) Variation in bat and bird fatalities at wind energy facilities: assessing the effects of rotor size and tower height. Can J Zool 85(3):381-387. doi:10.1139/ Z07-011

Barrios L, Rodríguez A (2004) Behavioural and environmental correlates of soaring-bird mortality at on-shore wind turbines. J Appl Ecol 41(1):72-81. doi:10.1111/j.1365-2664.2004.00876.x

Behr O, Eder D, Marckmann U, Mette-Christ H, Reisinger N, Runkel V, von Helversen O (2007) Akustisches Monitoring im Rotorbereich von Windenergieanlagen und methodische Probleme beim Nachweis von Fledermaus-Schlagopfern-Ergebnisse aus Untersuchungen im mittleren und südlichen Schwarzwald. Nyctalus 12(2-3):115-127

Behr O, Brinkmann R, Niermann I, Korner-Nievergelt F (2011) Akustische Erfassung der Fledermausaktivität an Windenergieanlagen. In Brinkmann $\mathrm{R}$, Behr O, Niermann I, Reich Michael (eds.) (2001) Entwicklung von Methoden zur Untersuchung und Reduktion des Kollisionsrisikos von Fledermäusen an Onshore-Windenergieanlagen. Umwelt und Raum, Cuvillier Verlag, Göttingen, Bd. 4: 177-286

Bellebaum J, Korner-Nievergelt F, Dürr T, Mammen U (2013) Wind turbine fatalities approach a level of concern in a raptor population. J Nat Conserv 21(6):394-400. doi:10.1016/j.jnc. 2013.06.001

Bennett VJ, Hale AM (2014) Red aviation lights on wind turbines do not increase bat-turbine collisions. Animal Conserv 17:354-358. doi:10.1111/acv.12102
Bergström L, Kautsky L, Malm T, Ohlsson H, Wahlberg M, Rosenberg R, Åstrand Capetillo N (2013a) Effects of offshore windfarms on marine wildlife-a synthesis for Swedish waters. Presentation CWE, Stockholm, Sweden 5-7 February, 2013. http://www.naturvardsverket.se/upload/miljoarbete-i-samhallet/ miljoarbete-i-sverige/forskning/vindval/cwe/Life\%20under\%20 the \%20surface/CWE_Bergstr\%C3\%B6m.pdf. Accessed 21 July 2014

Bergström L, Malm T, Åstrand Capetillo N, Ohlsson H, Wahlberg M, Rosenberg R, Kautsky L (2013b) Effects of off shore wind farms on marine wildlife - a risk assessment synthesis for Swedish waters. In: Naturvårdsverket (ed.) Book of Abstracts. Conference on Wind Power and Environmental Impacts Stockholm 5-7 February. Report 6546, Stockholm, Sweden, p 35

Bevanger K, Berntsen F, Clausen S, Dahl EL, Flagstad Ø, Follestad A et al. (2010) Pre- and post-construction studies of conflicts between birds and wind turbines in coastal Norway (Bird-Wind). Report on findings 2007-2010. Norwegian Institute for Nature Research (NINA) (ed.), Trondheim, Norway. http://www.nina. no/archive/nina/PppBasePdf/rapport/2010/620.pdf. Accessed 25 March 2014

Blackwell BF, Fernández-Juricic (2013) Behavior and physiology in the development and application of visual deterrents at airports. In: DeVault TL, Blackwell BF, Belant JL (eds) Wildlife management in airport environments. The Johns Hopkins University Press, Bltimore, pp 11-22

Blew J, Nehls G, Prall U (2013a) Offshore obstruction lighting Issues and mitigation. Presentation CWE, Stockholm, Sweden 5 7 February, 2013. http://www.naturvardsverket.se/upload/mil joarbete-i-samhallet/miljoarbete-i-sverige/forskning/vindval/ cwe/Mitigation $\% 20$ of\%20bird\%20and\%20bat\%20mortality/ Blew\%20CWE\%202013\%20Obstruction\%20Lighting\%20Off shore $\% 20$ Wind $\% 20$ farms $\% 20$ Mitigation $\% 20$ final.pdf. Accessed 21 July 2014

Blew J, Nehls G, Prall U (2013b) Offshore obstructions lightingIssues and mitigation. In: Naturvårdsverket (ed.): Book of Abstracts. Conference on Wind Power and Environmental Impacts Stockholm 5-7 February. Report 6546, Stockholm, Sweden, p 36

Brandt MJ, Diederichs A, Nehls G (2009) Harbour porpoise responses to pile driving at the Horns Rev II offshore wind farm in the Danish North Sea. Final Report to DONG Energy February 2009. BioConsult SH, Husum, Germany http://www.ens.dk/sites/ ens.dk/files/undergrund-forsyning/vedvarende-energi/vindkraftvindmoeller/havvindmoeller/miljoepaavirkninger-3/BioConsult $\% 20$ Harbour\%20porpoises.pdf. Accessed 21 July 2014

Brandt MJ, Diederichs A, Betke K, Nehls G (2011) Responses of harbour porpoises to pile driving at the Horns Rev II offshore wind farm in the Danish North Sea. Mar Ecol Prog Ser 421:205216. doi: $10.3354 / \mathrm{meps} 08888$

Brennan LA, Perez R, DeMaso S, Ballard BM, Kuvlesky WP (2009) Potential impacts of wind farm energy development on upland game birds: Questions and concerns. In: Rich TD, Demarest C, Arizmendi D, Thompson C (eds) Tundra to Tropics: Connecting Birds, Habitats and People. Proceedings of the Fourth International Partners in Flight Conference. McAllen, Texas, USA, 1316 February 2008, pp 179-183

Brinkmann R, Schauer-Weisshahn H, Bontadina F (2006) Untersuchungen $\mathrm{zu}$ möglichen betriebsbedingten Auswirkungen von Windkraftanlagen auf Fledermäuse im Regierungsbezirk Freiburg. Gundelfingen, Germany. http://www.rp-freiburg.de/ servlet/PB/show/1158478/rpf-wind-kraft-fledermaeuse.pdf. Accessed 7 August 2013

Brinkmann R, Behr O, Niermann I, Reich M (2011) Entwicklung von Methoden zur Untersuchung und Reduktion des Kollisionsrisikos von Fledermäusen an Onshore-Windenergieanlagen. 
Ergebnisse eines Forschungsvorhabens. Göttingen: Cuvillier (Umwelt und Raum, 4)

Bundesministerium für Umwelt, Naturschutz und Reaktorsicherheit (BMU) (2013) Offshore-Windenergie. Ein Überblick über die Aktivitäten in Deutschland. Berlin, Germany. http://www.offshorestiftung.com/Offshore/695/109/94/60005/design1.html. Accessed 21 July 2013

Bundesministerium für Umwelt, Naturschutz und Reaktorsicherheit (BMU) (2014) Konzept für den Schutz der Schweinswale vor Schallbelastungen bei der Errichtung von Offshore-Windparks in der deutschen Nordsee. (Schallschutzkonzept). http://www.bfn. $\mathrm{de} /$ fileadmin/MDB/documents/themen/erneuerbareenergien/Stra tegie_Positionspapiere/schallschutzkonzept_BMU.pdf. Accessed 30 January 2015

Burger J, Gordon C, Lawrence J, Newman J, Forcey G, Vlietstra L (2011) Risk evaluation for federally listed (roseate tern, piping plover) or candidate (red knot) bird species in offshore waters: a first step for managing the potential impacts of wind facility development on the Atlantic Outer Continental Shelf. Renew Energy 36(1):338-351. doi:10.1016/j.renene.2010.06.048

Burger J, Niles LJ, Porter RR, Dey AD, Koch S, Gordon C (2012) Using a shore bird (red knot) fitted with geolocators to evaluate a conceptual risk model focusing on offshore wind. Renew Energy 43:370-377. doi:10.1016/j.renene.2011.11.006

Camiña Á (2011) The effects of wind farms on vultures in Northern Spain-Fatalities behavior and correction measures. In: May R, Bevanger K (eds) Proceedings. Conference on Wind energy and Wildlife impacts. NINA Report 693. Conference on Wind energy and Wildlife impacts, 2-5 May 2011. Norwegian Institute for Nature Research. Trondheim, Norway, p 17

Carrete M, Sánchez-Zapata JA, Benítez JR, Lobón M, Montoya F, Donázar JA (2012) Mortality at wind-farms is positively related to large-scale distribution and aggregation in griffon vultures. Biol Conserv 145(1):102-108. doi:10.1016/j.biocon.2011.10.017

Carstensen J, Henriksen OD, Teilmann J (2006) Impacts of offshore wind farm construction on harbour porpoises: acoustic monitoring of echo-location activity using porpoise detectors (T-PODs). Mar Ecol Prog Ser 321:295-308. doi:10.3354/meps321295

Christensen TK, Hounisen JP, Clausager I, Petersen IK (2004) Visual and radar observations of birds in relation to collision risk at the Horns Rev offshore wind farm. Annual status report 2003. Report commissioned by Elsam Engineering A/S 2003. Edited by National Environmental Research Institute (NERI), Ministry of the Environment. Department of Wildlife Ecology and Biodiversity (NERI report). http://188.64.159.37/graphics/Ener giforsyning/Vedvarende_energi/Vind/havvindmoeller/vvm\%20 Horns\%20Rev\%202/Horns\%20Rev/fugle/Visual_radar_observa tions_2003_status_report.pdf. Accessed 18 March 2014

Cook ASCP, Johnston A, Wright LJ, Burton NHK (2012) A review of flight heights and avoidance rates of birds in relation to offshore wind farms. BTO Research Report No. 618. http://www.bto.org/ sites/default/files/u28/downloads/Projects/Final_Report_SOSS02_ BTOReview.pdf. Accessed 25 March 2014

Coppack T, Kulemeyer C, Schulz A, Steuri T, Liechti F (2011) Automated in situ monitoring of migratory birds at Germany's first offshore wind farm. In: May R, Bevanger $\mathrm{K}$ (eds): Proceedings of Conference on Wind energy and Wildlife impacts. NINA Report 693. Conference on Wind energy and Wildlife impacts, 2-5 May 2011. Norwegian Institute for Nature Research. Trondheim, Norway, p 20

Corten GP, Veldkamp HF (2001) Aerodynamics: insects can halve wind-turbine power. Nature 412:41-42. doi:10.1038/35083698

Cryan PM (2008) Mating Behavior as a Possible Cause of Bat Fatalities at Wind Turbines. J Wildl Manag 72(3):845-849. doi: $10.2193 / 2007-371$
Cryan PM, Barclay R (2009) Causes of Bat Fatalities at Wind Turbines: hypotheses and Predictions. J Mammal 90(6):1330 1340. doi:10.1644/09-MAMM-S-076R1.1

Cryan PM, Brown AC (2007) Migration of bats past a remote island offers clues toward the problem of bat fatalities at wind turbines. Biol Conserv 139(1-2):1-11. doi:10.1016/j.biocon.2007.05.019

Cryan PM, Gorresen MP, Hein CD, Schirmacher MR, Diehl RH, Huso MM (2014) Behavior of bats at wind turbines. Proc Natl Acad Sci. doi:10.1073/pnas.1406672111

Dahl EL, Bevanger K, Nygård T, Røskaft E, Stokke BG (2012) Reduced breeding success in white-tailed eagles at Smøla windfarm, western Norway, is caused by mortality and displacement. Biol Conserv 145(1):79-85. doi:10.1016/j.biocon.2011.10. 012

Dahl EL, May R, Hoel PL, Bevanger K, Pedersen HC, Røskaft E, Stokke BG (2013) White-tailed eagles (Haliaeetus albicilla) at the Smøla wind-power plant, Central Norway, lack behavioral flight responses to wind turbines. Wildl Soc Bull 37(1):66-74. doi: $10.1002 /$ wsb. 258

Dähne M, Gilles A, Lucke K, Peschko V, Adler S, Krügel K et al (2013) Effects of pile-driving on harbour porpoises (Phocoena phocoena) at the first offshore wind farm in Germany. Environ Res Lett 8(2):025002. doi:10.1088/1748-9326/8/2/025002

Dähne M, Peschko V, Gilles A, Lucke K, Adler S, Ronnenberg K, Siebert U (2014a) Marine mammals and windfarms: Effects of alpha ventus on harbour porpoises. In: Federal Maritime and Hydrographic Agency, Federal Ministry for the Environment, Nature Conservation and Nuclear Safety (eds) Ecological research at the offshore windfarm alpha ventus, Springer Fachmedien, Wiesbaden, pp 133-149

Dähne M, Gilles A, Schuster A, Ruser A, Siebert U (2014b) Ökologische Begleitforschung: Fokus Schweinswale-Wie gut schützen die aktuellen Schallschutzmaßnahmen vor schallinduzierten Störungen? 2. DUH-Schallschutztagung 2014—Wege zu einem wirksamen Unterwasserschallschutz beim Bau von Offshore-Windparks, Berlin, 07 May 2014. http://www.duh.de/ uploads/media/03_D\%C3\%A4hne.pdf. Accessed 13 June 2014

Danish Energy Agency (2013) Danish Offshore Wind. Key Environmental Issues-a Follow-up. 1st edn. Edited by The Environmental Group. The Danish Energy Agency; The Danish Nature Agency; DONG Energy; Vattenfall

de Lucas M, Janss GFE, Ferrer M (2004) The effects of a wind farm on birds in a migration point: the Strait of Gibraltar. Biodivers Conserv 13(2):395-407. doi:10.1023/B\%3ABIOC.0000006507. 22024.93

de Lucas M, Janss GFE, Ferrer M (2005) A Bird and Small Mammal BACI and IG Design Studies in a Wind Farm in Malpica (Spain). Biodivers Conserv 14(13):3289-3303. doi:10.1007/s10531-0040447-z

de Lucas M, Janss GFE, Whitfield DP, Ferrer M (2008) Collision fatality of raptors in wind farms does not depend on raptor abundance. J Appl Ecol 45(6):1695-1703. doi:10.1111/j.13652664.2008.01549.x

de Lucas M, Ferrer M, Bechard MJ, Muñoz Gallego A (2012a) Griffon vulture mortality at wind farms in southern Spain: distribution of fatalities and active mitigation measures. Biol Conserv 147(1):184-189. doi:10.1016/j.biocon.2011.12.029

de Lucas M, Ferrer M, Janss GFE, Magar V (2012b) Using wind tunnels to predict bird mortality in wind farms: the case of griffon vultures. Plos One 7(11):e48092. doi:10.1371/journal. pone. 0048092

Desholm M, Kahlert J (2005) Avian collision risk at an offshore wind farm. Biol Lett 1(3):296-298. doi:10.1098/rsbl.2005.0336

Devereux CL, Denny MJH, Whittingham MJ (2008) Minimal effects of wind turbines on the distribution of wintering farmland birds. 
J Appl Ecol 45(6):1689-1694. doi:10.1111/j.1365-2664.2008. 01560.x

Diederichs A, Hennig V, Nehls G (2008) Investigations of the bird collision risk and the responses of harbour porpoises in the offshore wind farms Horns Rev, North Sea, and Nysted, Baltic Sea, in Denmark. Part II: Harbour porpoises. Final Report 2008. Universität Hamburg; BioConsult SH GmbH and Co. KG. http:// bioconsult-sh.de/pdf/Final\%20Report\%20Offshore\%20Collision \%20Risk\%20Porpoises\%20DK\%2020081219.pdf. Accessed 18 July 2013

Doty AC, Martin AP (2012) Assessment of bat and avian mortality at a pilot wind turbine at Coega, Port Elizabeth, Eastern Cape. South Africa. N Z J Zool 40(1):75-80. doi:10.1080/03014223. 2012.741068

Douglas DJT, Bellamy PE, Pearce-Higgins JW (2011) Changes in the abundance and distribution of upland breeding birds at an operational wind farm. Bird Study 58(1):37-43. doi:10.1080/ 00063657.2010 .524914

Drewitt AL, Langston RHW (2006) Assessing the impacts of wind farms on birds. IBIS 148:29-42

Dürr T (2002) Fledermäuse als Opfer von Windkraftanlagen in Deutschland. Nyctalus 8(2):115-118

Dürr T (2003) Kollision von Fledermäuse und Vögel durch Windkraftanlagen. Daten aus Archiv der Staatlichen Vogelschutzwarte Brandenburgs. Edited by Staatliche Vogelschutzwarte Brandenburg. Buckow. http://www.lugv.brandenburg.de/cms/detail.php/ bb1.c.312579.de. Accessed 20 June 2013

Dürr T (2009) Zur Gefährdung des Rotmilans Milvus milvus durch Windenergieanlagen in Deutschland. Inf dienst Nat schutz Niedersachs. 29 (3):185-191

Dürr T (2011) Dunkler Anstrich könnte Kollisionen verhindern: vogelunfälle an Windradmasten. Falke 58(12):499-501

Eichhorn M, Johst K, Seppelt R, Drechsler M (2012) Model-based estimation of collision risks of predatory birds with wind turbines. Ecol Soc 17(2):1. doi:10.5751/ES-04594-170201

Erickson WP, Johnson GD, Young DP, Strickland MD, Good RE, Bourassa M et al. (2002) Synthesis and comparison of baseline avian and bat use, raptor nesting and mortality information from proposed and existing wind developments. Final. Edited by Western EcoSystems Technology Inc. Bonneville Power Administration. Cheyenne, WY

Erickson WP, Johnson GD, Young DP (2005) A Summary and Comparison of Bird Mortality from Anthropogenic Causes with an Emphasis on Collisions. Ralph CJ, Rich RD (eds): Bird Conservation Implementation and Integration in the Americas: Proceedings of the Third International Partners in Flight Conference. 2002 March 20-24; Asilomar, California, Vol. 2 Gen. Tech. Rep. PSW-GTR-191. Albany, CA: U.S. Dept. of Agriculture, Forest Service, Pacific Southwest Research Station, p 1029-1042

Everaert J (2014) Collision risk and micro-avoidance rates of birds with wind turbines in Flanders. Bird Study 61(2):220-230. doi:10.1080/00063657.2014.894492

Falkdalen Lindahl L, Falkdalen U, Nygård T (2013) Pre- and postconstruction studies on the effects on birds at Storrun wind farm in the mountain-region of Jämtland, Sweden. In Naturvårdsverket (ed.): Book of Abstracts. Conference on Wind Power and Environmental Impacts Stockholm 5-7 February. Conference on Wind Power and Environmental Impacts (CWE). Stockholm, 05.02.201307.02.2013. Stockholm, Sweden (Report, 6546), pp 53-54

Fiedler JK, Henry TH, Tankersley RD, Nicholson CP (2007) Results of Bat and Bird Mortality Monitoring at the Expanded Buffalo Mountain Windfarm, 2005. Tennessee Valley Authority (ed). http://www.tva.gov/environment/bmw_report/results.pdf. Accessed 30 July 2014
Fijn R, Krijgsveld K, Tijsen W, Prinsen H, Dirksen S (2012) Habitat use, disturbance and collision risks for Bewick's Swans Cygnus columbianus bewickii wintering near a wind farm in the Netherlands. In: Eileen C. Rees (ed): Wildfowl 62. With assistance of Anthony David Fox. Slimbridge, Gloucestershire: Wildfowl and Wetlands Trust (62), pp 97-116

Furmankiewicz J, Kucharska M (2009) Migration of bats along a large river valley in Southwestern Poland. J Mammal 90 (6):1310-1317. doi:10.1644/09-MAMM-S-099R1.1

Furness RW, Wade HM, Masden EA (2013) Assessing vulnerability of marine bird populations to offshore wind farms. J Environ Manag 119:56-66. doi:10.1016/j.jenvman.2013.01.025

Garthe S, Hüppop O (2004) Scaling possible adverse effects of marine wind farms on seabirds: developing and applying a vulnerability index. J Appl Ecol 41(4):724-734. doi:10.1111/j. 0021-8901.2004.00918.x

Garvin JC, Jennelle CS, Drake D, Grodsky SM (2011) Response of raptors to a windfarm. J Appl Ecol 48(1):199-209. doi:10.1111/j. 1365-2664.2010.01912.x

Gerdes F, Ludwig S (2014) Besonderheiten der Schallausbreitung in der Ostsee. DUH Schallschutztagung 2014-Wege zu einem wirksamen Unterwasserschallschutz beim Bau von OffshoreWindparks. Heinrich Böll Stiftung. Deutsche Umwelthilfe. Berlin, http://www.google.de/url?sa=tandrct=jandq=andesrc= sandsource $=$ webandcd $=1$ andved $=0 \mathrm{CCEQFjAAandurl}=\mathrm{http} \% 3 \mathrm{~A}$ $\% 2 \mathrm{~F} \% 2 \mathrm{Fwww}$.duh.de\%2Fuploads\%2Fmedia\%2F02_Gerdes_Lud wig.pdfandei=Zk-gVJCULMyqPN2HgPAFandusg=AFQjCNGFB wE-JWfcRx2eWSayAxFeFlFJFQandbvm=bv.82001339,d.bGQ. Accessed 13 June 2014

Gill AB (2005) Offshore renewable energy: ecological implications of generating electricity in the coastal zone. J Appl Ecol 42(4):605615. doi:10.1111/j.1365-2664.2005.01060.x

Gordon J (2012) Effects of Wind Farms on Marine Mammals: An Overview. Presentation OWEZ Congress, Amsterdam 11-12 October, 2012. http://noordzeewind.staging.netdesign.nl/wp-con tent/uploads/2012/11/pdf/OWE\%202012\%20Gordon\%20Over view $\% 20$ of $\% 20$ effects $\% 20$ on $\% 20$ marine $\% 20$ mammals.pdf. Accessed 8 Aug 2013

Gordon J, Thompson D, Gillespie D, Lonergan M, Calderan S, Jaffey B, Todd V (2007) Assessment of the potential for acoustic deterrents to mitigate the impact on marine mammals of underwater noise arising from the construction of offshore windfarms. Edited by COWRIE Ltd. St Andrews. http://mhk. pnnl.gov/wiki/images/c/cc/Gordon_et_al._2007.pdf. Accessed 17 Sep 2013

Grodsky SM, Behr MJ, Gendler A, Drake D, Dieterle BD, Rudd RJ, Walrath NL (2011) Investigating the causes of death for wind turbine-associated bat fatalities. J Mammal 92(5):917-925. doi:10.1644/10-MAMM-A-404.1

Grodsky SM, Jennelle CS, Drake D, Virzi T (2012) Bat mortality at a wind-energy facility in southeastern Wisconsin. Wildl Soc Bull 36(4):773-783. doi:10.1002/wsb.191

Grünkorn T (2013) Prediction and Assessment of collision risks at wind turbines in Germany. PROGRESS. With assistance of $\mathrm{v}$ Rönn J, Reichenbach M, Weitekamp S, Timmermann H, Coppack T, Meike K, Schleicher K. http://bioconsult-sh.de/pdf/ Gr\%C3\%BCnkorn2013_PROGRESS_CWE_DINAO.pdf. Accessed 11 March 2014

Grünkorn T, Diederichs A, Poszig D, Diederichs B, Nehls G (2009) Wie viele Vogel kollidieren mit Windenergieanlagen? How many birds collide with wind turbines? Nat Landsch 84(7):309314

Gue CT, Walker JA, Mehl KR, Gleason JS, Stephens SE, Loesch CR et al (2013) The effects of a large-scale wind farm on breeding season survival of female mallards and blue-winged teal in the 
Prairie Pothole Region. J Wildl Manag 77(7):1360-1371. doi:10. 1002/jwmg.583

Haelters J, Vanermen N (2013) Top Predators at Presentation. WINMON.BE conference, Brussels, 26-27 November 2013. http://www2.mumm.ac.be/downloads/winmonbe2013/day1/hael ters__vanermen_26_nov_2013_2.pdf. Accessed 22 July 2014

Haelters J, van Roy W, Vigin L, Degraer S (2012) The effect of pile driving on harbour porpoises in Belgian waters. In: Degraer S, Brabant R, Rumes B (eds) Offshore wind farms in the Belgian part of the North Sea. Heading for an understanding of environmental impacts. Royal Belgian Institute of Natural Sciences, Brussels, pp 127-143

Hatch SK, Connelly EE, Divoll TJ, Stenhouse IJ, Williams KA, Brown JD (2013) Offshore observations of eastern red bats (Lasiurus borealis) in the mid-atlantic united states using multiple survey methods. Plos One 8(12):e83803. doi:10.1371/ journal.pone.0083803

Hein CM, Zapka M, Mouritsen H (2011a) Weather significantly influences the migratory behaviour of night-migratory songbirds tested indoors in orientation cages. J Ornithol 152(1):27-35. doi:10.1007/s10336-010-0540-x

Hein CD, Schirmacher MR, Arnett EB, Huso MMP (2011b) Patterns of pre-construction bat acoustic activity at the proposed Resolute Wind Energy Project, Wyoming, 2009-2010. A final project report submitted to the Bats and Wind Energy Cooperative. Bat Conservation International. Austin, Texas, USA. http://www. batsandwind.org/pdf/Resolute\%20Report_FINAL.pdf. Accessed 22 July 2014

Helldin JO, Jung J, Neumann W, Olsson M, Skarin A, Widemo F (2012) The impacts of wind power on terrestrial mammals. A synthesis. Edited by Swedish Environmental Protection Agency (Report 6510). Stockholm, Sweden

Hill R, Hill K, Aumüller R, Schulz A, Dittmann T, Kulemeyer C, Coppack T (2014) Of birds, blades and barriers: Detecting and analyzing mass migration events at alpha ventus. In: Federal Maritime and Hydrographic Agency, Federal Ministry for the Environment, Nature Conservation and Nuclear Safety (eds.) Ecological Research at the Offshore Windfarm alpha ventus, Springer Fachmedien, Wiesbaden 2014, pp 111-131

Hoover S (2002) The Response of Red-Tailed Hawks and Golden Eagles to Topographical Features, Weather, and Abundance of a Dominant Prey Species at the Altamont Pass Wind Resource Area, California. April 1999-December 2000. Edited by National Renewable Energy Laboratory (NREL), Sacramento, California. http://www.nrel.gov/wind/pdfs/30868.pdf. Accessed 18 March 2014

Horn JW, Arnett EB, Kunz TH (2008) Behavioral responses of bats to operating wind turbines. J Wildl Manag 72(1):123-132. doi:10. 2193/2006-465

Hötker H (2006) Auswirkungen des "Repowering" von Windkraftanlagen auf Vögel und Fledermäuse. Edited by Michael-OttoInstitut. Bergenhusen, Germany

Hötker H, Thomsen K, Köster H (2005) Auswirkungen regenerativer Energiegewinnung auf die biologische Vielfalt am Beispiel der Vögel und der Fledermäuse. Edited by Bundesamt für Naturschutz (BfN). Naturschutzbund (NABU). Bonn, Germany (BfN-Skripten, 142)

Hötker H, Thomsen K, Köster H (2006) Impacts on biodiversity of exploitation of renewable energy sources: the example of birds and bats-facts, gaps in knowledge, demands for further research, and ornithological guidelines for the development of renewable energy exploitation. Michael-Otto-Institut im NABU, Bergenhusen

Houck DR (2012) Computational fluid dynamics simulations of bats flying near operating wind turbines: Quantification of pressuretime histories of likely flight paths. Available through the U.S. DOE Office of Science, Office of Workforce Development for
Teachers and Scientists Application Review System (WARS), 2012

Hull CL, Cawthen L (2013) Bat fatalities at two wind farms in Tasmania, Australia: bat characteristics, and spatial and temporal patterns. N Z J Zool 40(1):5-15. doi:10.1080/03014223.2012. 731006

Hull CL, Muir SC (2013) Behavior and turbine avoidance rates of eagles at two wind farms in Tasmania, Australia. Wildl Soc Bull 37(1):49-58. doi:10.1002/wsb.254

Hüppop O, Winkel W (2006) Climate change and timing of spring migration in the long-distance migrant Ficedula hypoleuca in central Europe: the role of spatially different temperature changes along migration routes. J Ornithol 147(2):344-353. doi:10.1007/s10336-005-0049-x

Hüppop O, Dierschke J, Wendeln H (2004) Zugvögel und OffshoreWindkraftanlagen: konflikte und Lösungen. Ber Vogelschutz 41:127-218

Hüppop O, Dierschke J, Exo K, Fredrich E, Hill R (2006) Bird migration studies and potential collision risk with offshore wind turbines. IBIS 148:90-109

Hüppop K, Dierschke J, Hill R, Hüppop O (2012) Jahres-und tageszeitliche Phänologie der Vogelrufaktivität über der Deutschen Bucht. Vogelwarte 50:87-108

IPCC (2013) Summary for Policymakers. In: Climate Change 2013: The Physical Science Basis. Contribution of Working Group I to the Fifth Assessment Report of the Intergovernmental Panel on Climate Change. Stocker TF, Qin D, Plattner GK, Tignor M, Allen SK, Boschung J, Nauels A, Xia Y, Bex V, Midgley PM (eds). Cambridge University Press, Cambridge, United Kingdom and New York, NY, USA

Isselbächer K, Isselbächer T (2001) Vogelschutz und Windenergie in Rheinland-Pfalz. Landesamt für Umweltschutz und Gewerbeaufsicht Rheinland-Pfalz (LfUG) (ed) Naturschutz und Landschaftspflege Rheinland-Pfalz 2/2001. http://www.luwg. rlp.de/icc/luwg/med/cd2/cd230ce7-fc18-6d01-33e2-dcfc638b24 9d,11111111-1111-1111-1111-111111111111.pdf. Accessed 15 January 2014

Jain A (2005) Bird and bat behavior and mortality at a northern Iowa windfarm. Master Thesis. Iowa State University, Arnes, Iowa, USA. http://batsandwind.org/pdf/Jain_2005.pdf. Accessed 26 August 2013

Johnson GD, Erickson WP, Strickland MD, Shepherd M, Shepherd D, Sarappo S (2003) Mortality of Bats at a Large-scale Wind Power Development at Buffalo Ridge, Minnesota. Am Midl Nat 150 (2):332-342. doi:10.1674/0003-0031(2003)150

Johnson GD, Perlik MK, Erickson WP, Strickland MD (2004) Bat activity, composition, and collision mortality at a large wind plant in Minnesota. Wildl Soc Bull 32(4):1278-1288. doi:10. 2193/0091-7648(2004)032

Johnson JS, Watrous KS, Giumarro GJ, Peterson TS, Boyden SA, Lacki MJ (2011) Seasonal and geographic trends in acoustic detection of tree-roosting bats. Acta Chiropterolog. 13(1):157168. doi:10.3161/150811011X578705

Kahlert JA, Laubek B, Aaen K, Waagner S, Groom G, Andersen PN (2011) Rødsand 2 Offshore Wind Farm-Post-construction Studies on Migrating Land Birds autumn 2010. http://www. ens.dk/sites/ens.dk/files/undergrund-forsyning/vedvarende-energi/ vindkraft-vindmoeller/havvindmoeller/miljoepaavirkninger/Roed sand/eon_roedsand2_land_bird_migration_post_construction_2010. pdf. Accessed 27 Dec 2014

Kastelein RA (2013a) Harbor seals and harbor porpoises- pile driving: detection, behavioral response and TTS. Presentation at the WINMON.BE conference, Brussels, Belgium, 26-27 November 2013. http://www2.mumm.ac.be/downloads/winmonbe2013/day2/ kastelein_ron_2013g,_effect_pile_driving_on_porpoises__seals. pdf. Accessed 25 April 2014 
Kastelein RA, van Heerden D, Gransier R, Hoek L (2013) Behavioral responses of a harbor porpoise (Phocoena phocoena) to playbacks of broadband pile driving sounds. Mar Environ Res 92:206-214. doi:10.1016/j.marenvres.2013.09.020

Katzner TE, Brandes D, Miller T, Lanzone M, Maisonneuve C, Tremblay JA et al (2012) Topography drives migratory flight altitude of golden eagles: implications for on-shore wind energy development. J Appl Ecol 49(5):1178-1186. doi:10.1111/j.13652664.2012.02185.x

Kerns J, Erickson WP, Arnett EB (2005) Bat and bird fatality at wind energy facilities in Pennsylvania and West Virginia, chapter 2: 24-95. In: Arnett EB (tech. ed.): Relationships between bats and wind turbines in Pennsylvania and West Virginia: an assessment of fatality search protocols, patterns of fatality, and behavioral interactions with wind turbines. A final report submitted to the Bats and Wind Energy Cooperative. Bat Conservation International. Austin, Texas, USA. http://www.batsandwind.org/pdf/ ar2004.pdf. Accessed 20 June 2013

Knopper LD, Ollson CA (2011) Health effects and wind turbines: a review of the literature. Environ Health 10(1):78. doi:10.1186/ 1476-069X-10-78

Köppel J, Dahmen M, Helfrich J, Schuster E, Bulling L (2014) Cautious but committed: moving towards adaptive planning and operation strategies for renewable energy's wildlife implications. Environ Manag. doi:10.1007/s00267-014-0333-8

Koschinski S, Culik BM, Henriksen OD, Tregenza N, Ellis G, Jansen C, Kathe G (2003) Behavioural reactions of free-ranging porpoises and seals to the noise of a simulated $2 \mathrm{MW}$ wind power generator. Mar Ecol Prog Ser 265:263-273. doi:10.3354/ meps 265263

Kreuzinger J (2008) Kulissenwirkung und Vögel. Methodische Rahmenbedingungen für die Auswirkungsanalyse in der FFH-VP. Vilmer Expertentagung 29.09.-01.10.2008. http://www.bfn.de/ fileadmin/MDB/documents/ina/vortraege/2008-FFH-VP_Gesamt. pdf. Accessed 13 January 2014

Kunz TH, Arnett EB, Erickson WP, Hoar AR, Johnson GD, Larkin RP et al (2007) Ecological impacts of wind energy development on bats: questions, research needs, and hypotheses. Front Ecol Environ 5(6):315-324. doi:10.1890/1540-9295(2007)5

Langgemach T, Dürr T (2013) Informationen über Einflüsse der Windenergienutzung auf Vögel. Edited by Staatliche Vogelschutzwarte Brandenburg. Nennhausen, Germany. http:// www.lugv.brandenburg.de/media_fast/4055/vsw_dokwind_voegel. pdf. Accessed 22 July 2014

Larsen JK, Madsen J (2000) Effects of wind turbines and other physical elements on field utilization by pink-footed geese (Anser brachyrhynchus): a landscape perspective. Landsc Ecol 15(8):755-764. doi:10.1023/A:1008127702944

LeBeau CW, Beck JL, Johnson GD, Holloran MJ (2014) Short-term impacts of wind energy development on greater sage-grouse fitness. J Wildl Manag 78(3):522-530. doi:10.1002/jwmg.679

Leddy KL, Higgins KF, Naugle DE (1999) Effects of wind turbines on upland nesting birds in Conservation Reserve Program grasslands. Wilson Bull 111(1):100-104

Ledec G, Rapp KW, Aiello R (2011) Greening the Wind. Environmental and social considerations for wind power development. World Bank (ed.) Washington D.C, USA

Lindeboom HJ (2012) Offshore Wind Farms, new players in marine ecosystems. Presentation at OWEZ Congress, Amsterdam, Netherlands 11-12 October, 2012. http://www.noordzeewind. $\mathrm{nl} /$ wp-content/uploads/2012/11/pdf/OWE\%202012\%20Imares\% 20Lindeboom $\% 20$ New\%20players $\% 20$ in $\% 20$ marine $\% 20$ ecosys tems.pdf. Accessed 22 July 2014

Lippert T, Heitmann K, Ruhnau M, Lippert S, von Estorff O (2014) Numerische Vorhersage von Rammschall in Wasser und Boden. 2. DUH Schallschutztagung 2014-Wege zu einem wirksamen
Unterwasserschallschutz beim Bau von Offshore-Windparks, Berlin 07 May 2014. http://www.duh.de/uploads/media/09_ Lippert.pdf. Accessed 13 June 2014

Long CV, Flint JA, Lepper PA, Dible SA (2009) Wind turbines and bat mortality: interactions of bat echolocation pulses with moving turbine rotor blades. In: Fifth International Conference on Bio-acoustics 2009, 31st March-2nd April 2009, Loughborough. Proceedings of the Institute of Acoustics 31 (1): 183-190

Loss SR, Will T, Marra PP (2013) Estimates of bird collision mortality at wind facilities in the contiguous United States. Biol Conserv 168:201-209. doi:10.1016/j.biocon.2013.10.007

Lovich JE, Ennen JR (2013) Assessing the state of knowledge of utility-scale wind energy development and operation on nonvolant terrestrial and marine wildlife. Appl Energy 103:52-60. doi:10.1016/j.apenergy.2012.10.001

Lucke K (2008b) Auditory studies on harbour porpoises in relation to offshore wind turbines. In: Evens EGH (ed.) Proceedings of the Ascobans/Ecs Workshop-Offshore wind farms and marine mammals: impacts and methodologies for assessing impacts. Ecs special publication series (49): 17-20. http://www.ascobans.org/ sites/default/files/document/MOP6_5-06_WindFarmWorkshop_ 1.pdf. Accessed 22 July 2014

Lucke K, Sundermeyer J, Driver J, Rosenberger T, Siebert U (2008) Too loud to talk? Do wind turbine-related sounds affect harbour seal communication? In: Esklidsen K (ed) Wollny-Goerke K. Teubner, Marine mammals and seabirds in front of offshore wind energy. MINOS-marine warm-blooded animals in North and Baltic Seas. Wiesbaden, pp 95-110

Lucke K, Siebert U, Lepper PA, Blanchet M (2009) Temporary shift in masked hearing thresholds in a harbor porpoise (Phocoena phocoena) after exposure to seismic airgun stimuli. J Acoust Soc Am 125(6):4060-4070

Lucke K, Dähne M, Adler S, Brandecker A, Krügel K, Sundermeyer JK, Siebert U (2012) Evaluating the Effects of Offshore Pile Driving on Phocoena phocoena (Harbor Porpoises) by Using Passive Acoustic Monitoring. In: Popper AN, Hawkins A (eds) The Effects of Noise on Aquatic Life. Advances in Experimental Medicine and Biology (730). Springer, New York, pp 285-287

Madders M, Whitfield DP (2006) Upland raptors and the assessment of wind farm impacts. IBIS 148:43-56. doi:10.1111/j.1474919X.2006.00506.X

Madsen J, Boertmann D (2008) Animal behavioral adaptation to changing landscapes: spring-staging geese habituate to wind farms. Landsc Ecol 23(9):1007-1011. doi:10.1007/s10980-008-9269-9

Madsen PT, Wahlberg M, Tougaard J, Lucke K, Tyack PL (2006) Wind turbine underwater noise and marine mammals: implications of current knowledge and data needs. Mar Ecol Prog Ser 309:279-295

Mammen U, Mammen K, Heinrichs N, Resetaritz A (2011) Red kite (Milvus Milvus) fatalities at wind turbines-Why do they occur and how they are to prevent? In: May R, Bevanger K (eds) Proceedings of Conference on Wind energy and Wildlife impacts. NINA Report 693. Conference on Wind energy and Wildlife impacts, 2-5 May 2011. Norwegian Institute for Nature Research. Trondheim, Norway, p 108

Martínez-Abraín A, Tavecchia G, Regan HM, Jiménez J, Surroca M, Oro D (2012) Effects of wind farms and food scarcity on a large scavenging bird species following an epidemic of bovine spongiform encephalopathy. J Appl Ecol 49(1):109-117. doi:10.1111/j.1365-2664.2011.02080.x

Masden EA, Haydon DT, Fox AD, Furness RW, Bullman R, Desholm M (2009) Barriers to movement: impacts of wind farms on migrating birds. ICES J Mar Sci 66:746-753. doi:10.1093/ icesjms/fsp031

Matuschek R, Betke K (2009) Measurements of Construction Noise During Pile Driving of Offshore Research Platforms and Wind 
Farms. NAG/DAGA Rotterdam. http://www.itap.de/ daga09rmkb.pdf. Accessed 26 August 2013

May R, Hoel PL, Langston RHW, Dahl EL, Bevanger K, Reitan O et al. (2010) Collision risk in white-tailed eagles. Modelling collision observations in Smøla wind-power plant. Edited by Norwegian Institute for Nature Research (NINA Report, 639). http://www.nina.no/archive/nina/pppbasepdf/rapport/2010/639.pdf. Accessed 22 July 2014

May R, Nygård T, Dahl EL, Reitan O, Bevanger K (2011) Collision risk in white-tailed eagles. Modelling kernel-based collision risk using satellite telemetry data in Smøla wind-power plant. Edited by Norwegian Institute for Nature Research (NINA Report, 692). http://www.nina.no/archive/nina/pppbasepdf/rapport/2011/692.pdf. Accessed 22 July 2014

McConnell B, Lonergan M, Dietz R (2012) Marine Estate Research Report: Interactions between seals and offshore wind farms. http:// www.thecrownestate.co.uk/media/288846/interactions_between_ seals_and_offshore_wind_farms.pdf. Accessed 23 April 2014

McNew LB, Hunt LM, Gregory AJ, Wisely SM, Sandercock BK (2014) Effects of wind energy development on nesting ecology of greater prairie-chickens in fragmented grasslands. Conserv Biol 28(4):1089-1099. doi:10.1111/cobi.12258

Morinha F, Travassos P, Seixas F, Martins A, Bastos R, Carvalho D et al (2014) Differential mortality of birds killed at wind farms in Northern Portugal. Bird Study 61(2):255-259. doi:10.1080/ 00063657.2014.883357

Muños Gallego A, de Lucas M, Casado E, Ferrer M (2011) Raptor mortality in wind farms of southern Spain: mitigation measures on a major migration bottleneck area. In: May R, Bevanger K (eds) Proceedings of Conference on Wind energy and Wildlife impacts. NINA Report 693. Conference on Wind energy and Wildlife impacts, 2-5 May 2011. Norwegian Institute for Nature Research. Trondheim, Norway, p 42

Mateos M. Muñoz Arroyo G, Alonso del Rosario JJ (2011) Modelling seabird collision risk with off-shore windfarms. In May R, Bevanger K (eds) Proceedings of Conference on Wind energy and Wildlife impacts. NINA Report 693. Conference on Wind energy and Wildlife impacts, 2-5 May 2011. Norwegian Institute for Nature Research. Trondheim, Norway, p 39

Nedwell J, Howell D (2004) A review of offshore windfarm related underwater noise sources. Tech. Rep. 544R0308. Prep. By Subacoustech Ltd., Hampshire, UK, for COWRIE. http://www. subacoustech.com/information/downloads/reports/544r0308.pdf. Accessed 27 September 2013

Nedwell J, Parvin S, Edwards B, Workman R, Booker A, Kynoch JE (2007) Measurement and interpretation of underwater noise during construction and operation of offshore windfarms in UK waters. Subacoustech Report No. 544R0738 to COWRIE Ltd

Nehls G, Betke K (2011) Darstellung und Bewertung der Auswirkungen von Schallemissionen durch offshore-Rammarbeiten auf Meeressäugetiere. http://www.bioconsult-sh.de/pdf/Nehls\%20 and\%20Bethke\%202011\%20Schallbericht\%20OFW20111215.pdf. Accessed 4 March 2014

Nilsson ALK, Alerstam T, Nilsson J, Holberton RL (2006) Do partial and regular migrants differ in their responses to weather? Auk 123(2):537-547. doi:10.1642/0004-8038(2006)123[537: DPARMD]2.0.CO;2

Orloff S, Flannery A (1992) Wind turbine effects on avian activity, habitat use, and mortality in Altamont Pass and Solano County wind resource areas, 1989-1991. Consultant Report. http://www. energy.ca.gov/windguidelines/documents/2006-12-06_1992_FINAL_ REPORT_1989-1991.PDF. Accessed 22 July 2014

Pearce-Higgins JW, Stephen L, Langston RHW, Bright J (2008) Assessing the cumulative impacts of wind farms on peatland birds: a case study of golden plover Pluvialis apricaria in Scotland. Mires and Peat 4 (2008/9) Article 01. ISSN 1819-754X
Pearce-Higgins JW, Stephen L, Langston RHW, Bainbridge IP, Bullman R (2009) The distribution of breeding birds around upland wind farms. J Appl Ecol 46(6):1323-1331. doi:10.1111/j. 1365-2664.2009.01715.x

Pearce-Higgins JW, Stephen L, Douse A, Langston RHW (2012) Greater impacts of wind farms on bird populations during construction than subsequent operation: results of a multi-site and multi-species analysis. J Appl Ecol 49(2):386-394. doi:10. 1111/j.1365-2664.2012.02110.x

Percival SM (2003) Birds and Windfarms in Ireland. A review of potential issues and impact assessment. Ecology Consulting. Durham, UK. http://www.sustainableenergyireland.ie/uploaded files/RenewableEnergy/AssessmentMethodologyBirdsIreland.pdf. Accessed 20 June 2013

Petersen IK, Christensen TK, Kahlert J, Desholm M, Fox AD (2006) Final results of bird studies at the offshore wind farms at Nysted and Horns Rev, Denmark: Report request. Commissioned by DONG Energy and Vattenfall A/S. National Environmental Research Institute, 2006. http://www.folkecenter.net/mediafiles/ folkecenter/pdf/Final_results_of_bird_studies_at_the_offshore_ wind_farms_at_Nysted_and_Horns_Rev_Denmark.pdf. Accessed 27 Dec 2014

Pettersson J (2005) The Impact of Offshore Wind Farms on Bird Life in Southern Kalmar Sound, Sweden. A final report based on studies 1999-2003. http://www.textbruket.se/kalmarsund/Kal marsund_EN.pdf. Accessed 27 Dec 2014

Pettersson J, Fågelvind JP (2011) Night migration of songbirds and waterfowl at the Utgrunden off-shore wind farm. A radarassisted study in southern Kalmar Sound. Report 6438, Stockholm, Sweden

Piorkowski MD, O'Connell TJ (2010) Spatial pattern of summer bat mortality from collisions with wind turbines in mixed-grass prairie. A Midl Nat 164(2):260-269. doi:10.1674/0003-0031164.2.260

Plonczkier P, Simms IC (2012) Radar monitoring of migrating pinkfooted geese: behavioural responses to offshore wind farm development. J Appl Ecol 49(5):1187-1194. doi:10.1111/j.13652664.2012.02181.x

Powlesland RG (2009) Bird species of concern at wind farms in New Zealand. DOC Research and Development Series 317. Wellington, New Zealand, $54 \mathrm{pp}$

Prior A, McMath MJ (2008) Marine mammals and noise from offshore renewable energy projects-UK developments. In: Evens EGH (ed) Proceedings of the Ascobans/Ecs Workshop -Offshore wind farms and marine mammals: impacts and methodologies for assessing impacts. Ecs special publication series (49): 12-16. http://www.ascobans.org/sites/default/files/ document/MOP6_5-06_WindFarmWorkshop_1.pdf. Accessed 22 July 2014

Pruett CL, Patten MA, Wolfe DH (2009a) Avoidance behavior by prairie grouse: implications for development of wind energy. Conserv Biol 23(5):1253-1259. doi:10.1111/j.1523-1739.2009.01254.x

Pruett CL, Patten MA, Wolfe DH (2009b) It's not easy being green: wind energy and a declining grassland bird. Bioscience 59 (3):257-262. doi:10.1525/bio.2009.59.3.10

Redell D, Arnett EB, Hayes JP, Huso MMP (2006) Patterns of preconstruction bat activity determined using acoustic monitoring at a proposed wind facility in south-central Wisconsin. A final report submitted to the Bats and Wind Energy Cooperative. Bat Conservation International. Austin, Texas, USA. http://www. batsandwind.org/pdf/precon_wi.pdf. Accessed 25 June 2013

Rees EC (2012) Impacts of wind farms on swans and geese. A review. In: Rees EC (ed.) Wildfowl 62. Wildfowl and Wetlands Trust (62): 37-72. http://www.wwt.org.uk/uploads/documents/ 1354572544_Wildfowl62.pdf\#page=41. Accessed 26 August 2013 
Reichenbach M, Grünkorn T (2011) A multi-method approach to determine the impact of existing wind power plants on bird and bat migration on the island of Fehmarn, Germany. In: May R, Bevanger K (eds.) Proceedings. Conference on Wind energy and Wildlife impacts. NINA Report 693. Conference on Wind energy and Wildlife impacts, 2-5 May 2011. Norwegian Institute for Nature Research. Trondheim, Norway, p 118

Reichenbach M, Steinborn H (2006) Windkraft, Vögel, LebensräumeErgebnisse einer fünfjährigen BACI-Studie zum Einfluss von Windkraftanlagen und Habitatparametern auf Wiesenvögel. Osnabrücker Naturwissenschaftliche Mitteilungen 32:243-259

Rollins KE, Meyerholz DK, Johnson GD, Capparella AP, Loew SS (2012) A forensic investigation into the etiology of bat mortality at a wind farm: barotrauma or traumatic injury? Vet Pathol 49 (2):362-371

Russell DJ, Brasseur SMJM, Thompson D, Hastie GD, Janik VMJ, Aarts $G$ et al (2014) Marine mammals trace anthropogenic structures at sea. Curr Biol 24(14):638-639. doi:10.1101/ cshperspect.a002774

Rydell J, Bach L, Dubourg-Savage M, Green M, Rodrigues L, Hedenström A (2010a) Bat mortality at wind turbines in northwestern europe. Acta Chiropterolog 12(2):261-274. doi:10.3161/150811010X537846

Rydell J, Bach L, Dubourg-Savage M, Green M, Rodrigues L, Hedenström A (2010b) Mortality of bats at wind turbines links to nocturnal insect migration? Eur J Wildl Res 56(6):823-827. doi:10.1007/s10344-010-0444-3

Rydell J, Engström H, Hedenström A, Larsen JK, Pettersson J, Green M (2012) The effect of wind power on birds and bats. A synthesis. Report 6511, August 2012. Swedish Environmental Protection Agency (ed), Stockholm Sweden

Sandercock BK, Wisely SM, McNew LB, Gregory AJ, Winder VL, Hunt LM (2013) Environmental impacts of wind power development on the population biology of greater prairie-chickens. http://www.osti.gov/scitech/servlets/purl/1080446. Accessed 22 July 2014

Scheidat M (2012) Porpoises and offshore windfarms-conflict, coexistence or refuge? Presentation at OWEZ Congress, Amsterdam, Netherlands, 11-12 October 2012. http://www.noordzee wind.nl/wp-content/uploads/2012/11/pdf/OWE\%202012\%20 Imares $\% 20$ Scheidat $\% 20$ Harbor\%20Porpoises.pdf. Accessed 22 July 2014

Scheidat M, Tougaard J, Brasseur S, Carstensen J, van Polanen-Petel T, Teilmann J, Reijnders PJH (2011) Harbour porpoises (Phocoena phocoena) and wind farms: a case study in the Dutch North Sea. Environ Res Lett 6(2):25102. doi:10.1088/17489326/6/2/025102

Sea Mammal Research Unit (SMRU) (2009) Strategic review of Offshore Wind Farm Monitoring Data Associated with FEPA License Conditions: Marine Mammals (version 1.2, 28 August 2009). http://www.cefas.defra.gov.uk/media/393581/annex-6marine-mammals.pdf. Accessed 17 September 2013

Shamoun-Baranes J, van Loon E, Alon D, Alpert P, Yom-Tov Y, Leshem Y (2006) Is there a connection between weather at departure sites, onset of migration and timing of soaring-bird autumn migration in Israel? Glob Ecol and Biogeogr 15(6):541552. doi:10.1111/j.1466-8238.2006.00261.x

Simmonds M, Brown VC (2010) Is there a conflict between cetacean conservation and marine renewable-energy developments? Wildl Res 37(8):688-694. doi:10.1071/WR10020

Simmonds M, Dolman S (2008) All at sea: renewable energy production in the context of marine nature conservation. In: Evens EGH (ed.) Proceedings of the Ascobans/Ecs WorkshopOffshore wind farms and marine mammals: impacts and methodologies for assessing impacts. Ecs special publication series (49): 6-11. http://www.ascobans.org/sites/default/files/
document/MOP6_5-06_WindFarmWorkshop_1.pdf. Accessed 22 July 2014

Simms W, Ross PS (2000) Vitamin A physiology and its application as a biomarker of contaminant-related toxicity in marine mammals: a review. Toxicol Ind Health 16(7-8):291-302. doi:10.1177/074823370001600706

Sjollema AL, Gates JE, Hilderbrand RH, Sherwell J (2014) Offshore activity of bats along the mid-atlantic coast. Northeastern Naturalist 21(2):154-163. doi:10.1656/045.021.0201

Smallwood KS, Thelander CG (2004) Developing methods to reduce bird mortality in the Altamont Pass Wind Resource Area. Pier final project report. Edited by BioResource Consultants. http:// www.energy.ca.gov/reports/500-04-052/500-04-052_00_EXEC_ SUM.PDF. Accessed 22 July 2014

Smallwood KS, Thelander CG (2008) Bird mortality in the altamont pass wind resource area, California. J Wildl Manag 72(1):215223. doi: $10.2193 / 2007-032$

Smallwood KS, Thelander CG, Morrison ML, Rugge LM (2007) Burrowing owl mortality in the altamont pass wind resource area. J Wildl Manag 71(5):1513-1524. doi:10.2193/2006-307

Smallwood KS, Rugge LM, Morrison ML (2009) Influence of behavior on bird mortality in wind energy developments. J Wildl Manag 73(7):1082-1098. doi:10.2193/2008-555

Steinborn H, Reichenbach M (2012) Einfluss von Windenergieanlagen auf den Ortolan Emberiza hortulana in Relation zu weiteren Habitatparametern. Vogelwelt 133:59-75

Steinborn H, Reichenbach M, Timmermann H (2011) WindkraftVögel-Lebensräume. Ergebnisse einer siebenjährigen Studie zum Einfluss von Windkraftanlagen und Habitatparametern auf Wiesenvögel. ARSU GmbH (ed.). Norderstedt, Germany

Stevens TK, Hale AM, Karsten KB, Bennett VJ (2013) An analysis of displacement from wind turbines in a wintering grassland bird community. Biodivers Conserv 22(8):1755-1767. doi:10.1007/ s10531-013-0510-8

Stewart G, Pullin A, Coles C (2007) Poor evidence-base for assessment of windfarm impacts on birds. Environ Conserv 34 (1): $1-11$

Stienen EWM, Waeyenberge V, Kuijken E, Seys J (2007) Trapped within the corridor of the Southern North Sea: The potential impact of offshore wind farms on seabirds. In de Lucas M, Janss GFE, Ferrer M (eds): Birds and wind farms. Risk assessment and mitigation. 1st ed. Madrid: Quercus, pp 71-80

Teilmann J, Tougaard J, Carstensen J (2012) Effects on harbour porpoises from Rødsand 2 Off-shore Wind Farm. Edited by Aarhus University, Danish Centre for Environment and Energy (DCE). Scientific Report from DCE-Danish Centre for Environment and Energy No. 42. http://www.dmu.dk/Pub/SR42.pdf. Accessed 22 July 2014

Thompson PM, Lusseau D, Barton T, Simmons D, Rusin J, Bailey H (2010) Assessing the responses of coastal cetaceans to the construction of offshore wind turbines. Mar Pollut Bull 60 (8):1200-1208. doi:10.1016/j.marpolbul.2010.03.030

Thompson PM, Hastie GD, Nedwell J, Barham R, Brookes KL, Cordes LS et al (2013) Framework for assessing impacts of piledriving noise from offshore wind farm construction on a harbour seal population. Environ Impact Asses 43:73-85. doi:10.1016/j. eiar.2013.06.005

Tougaard J (2013) Offshore wind farms and the marine environment -lessons from the Danish demonstration project and elsewhere. In: Naturvårdsverket (ed): Book of Abstracts. Conference on Wind Power and Environmental Impacts Stockholm 5-7 February. Report 6546, Stockholm, Sweden. p 25

Tougaard J, Carstensen J, Ilsted Bech N, Teilmann J (2006a) Final report on the effect of Nysted Offshore Wind Farm on harbour porpoises. Technical report to Energi E2 A/S. Edited by Ministry of the Environment. National Environmental Research Institute 
(NERI). Roskilde, Denmark. http://188.64.159.37/graphics/Ener giforsyning/Vedvarende_energi/Vind/havvindmoeller/vvm\% 20Horns\%20Rev\%202/Nysted/Nysted\%20marsvin\%20final.pdf. Accessed 22 July 2014

Tougaard J, Carstensen J, Wisz M, Jespersen M, Teilmann J, Ilsted Bech N, Skov H (2006b) Harbour Porpoises on Horns Reef. Effects of the Horns Reef Wind Farm. Final Report to Vattenfall A/S. Roskilde, Denmark. http://tethys.pnnl.gov/sites/default/ files/publications/Jakob_et_al_2006.pdf. Accessed 22 July 2014

Tougaard J, Carstensen J, Teilmann J, Skov H, Rasmussen P (2009a) Pile driving zone of responsiveness extends beyond $20 \mathrm{~km}$ for harbor porpoises (Phocoena phocoena (L.)). J Acoust Soc Am 126(1):11-14. doi:10.1121/1.3132523

Tougaard J, Henriksen OD, Miller LA (2009b) Underwater noise from three types of offshore wind turbines: estimation of impact zones for harbor porpoises and harbor seals. J Acoust Soc Am 125(6):3766-3773. doi:10.1121/1.3117444

Tougaard J, Kyhn LA, Amundin M, Wennerberg D, Bordin C (2012) Behavioral Reactions of Harbor Porpoise to Pile-Driving Noise. In: Popper AN, Hawkins A (eds) The Effects of Noise on Aquatic Life. Advances in Experimental Medicine and Biology (730). Springer, New York, pp 277-280

van de Laar FJT (2007) Green light to birds. Investigation into the effect of bird-friendly lighting. http://www.waddenzee.nl/filead $\mathrm{min} /$ content/Dossiers/Energie/pdf/green_light_to_birdsNAM.pdf. Accessed 25 March 2014

van Hal R, Griffioen B (2012) The local fish community, indifferent to the wind farm? Presentation at OWEZ Congress, Amsterdam, Netherlands, 11-12 October 2012. http://www.noordzeewind.nl/ wp-content/uploads/2012/11/pdf/OWE\%202012\%20Imares\%20 Van\%20Hal\%20Fish.pdf. Accessed 22 July 2014

Voigt CC, Popa-Lisseanu AG, Niermann I, Kramer-Schadt S (2012) The catchment area of wind farms for European bats: a plea for international regulations. Biol Conserv 153:80-86. doi:10.1016/ j.biocon.2012.04.027

Wahl V, Braasch A, Joost M, Ketzer C, Michalik A, Todeskino D (2013) Behavioural responses of harbour porpoises to pile driving on a temporal and spatial scale at the "BARD Offshore 1" windfarm. Presentation at StuKplus-Five Years of Ecological Research at alpha ventus-Challenges, Results and Perspectives, Berlin 30 October 2013. http://stukplusconfer ence.com/wp-content/uploads/2013/12/Presentation_Wahl\%20et
\%20al_Behavioural\%20responses\%20of\%20harbour\%20porpoises $\% 20$ to $\% 20$ pile $\% 20$ driving $\% 20$ on $\% 20$ a $\% 20$ temporal $\% 20$ and $\%$ 20spatial $\% 20$ scale $\% 20$ at $\% 20$ the $\% 20 \%$ E2\%80\%9CBARD $\% 20$ Off shore $\% 201 \% \mathrm{E} 2 \% 80 \% 9 \mathrm{D} \% 20$ windfarm.pdf. Accessed 25 April 2014

Walters K, Kosciuch K, Jones J (2013) A Critical Review of the Effects of Tall Structures on Birds. In: Naturvårdsverket (ed): Book of Abstracts. Conference on Wind Power and Environmental Impacts (CWE2013) Stockholm 5-7 February. Report 6546, Stockholm, Sweden. p 106

Whitfield DP, Madders M (2006) A review of the impacts of wind farms on hen harriers Circus cyaneus and an estimation of collision avoidance rates. Natural Research Information Note 1 (revised). Edited by Natural Research Ltd. Banchory, UK

Willis CKR, Barclay RMR, Boyles JG, Brigham RM, Brack V Jr, Waldien DL (2009) Reichard J (2009) Bats are not birds and other problems with Sovacool's (2009) analysis of animal fatalities due to electricity generation. Energy Policy. doi:10. 1016/j.enpol.2009.08.034

Winder VL, McNew LB, Gregory AJ, Hunt LM, Wisely SM, Sandercock BK (2013) Effects of wind energy development on survival of female greater prairie-chickens. J Appl Ecol. doi: 10. 1111/1365-2664.12184

Winder VL, McNew LB, Gregory A, Hunt LM, Wisely SM, Sandercock BK (2014) Space use by female Greater PrairieChickens in response to wind energy development. Ecosphere. doi:10.1890/ES13-00206.1

Winter E, Aarts G, van Keeken O (2012) Cod and sole behaviour in an offshore wind farm. Presentation at OWEZ Congress, Amsterdam, Netherlands. 11-12 October 2012. http://www. noordzeewind.n1/wp-content/uploads/2012/11/pdf/OWE\%20201 $2 \% 20$ Imares $\% 20$ Winter $\% 20$ Cod $\% 20$ and $\% 20$ Sole $\% 20$ behaviour. pdf. Accessed 5 September 2013

Zeiler HP, Gruenschachner-Berger V (2009) Impact of wind power plants on black grouse, Lyrurus tetrix in Alpine regions. Folia Zool 58(2):173-182

Zimmerling JR, Pomeroy AC, d'Entremont MV, Francis CM (2013) Canadian estimate of bird mortality due to collisions and direct habitat loss associated with wind turbine developments. Avian Conserv Ecol. doi:10.5751/ACE-00609-080210 